\title{
The importance of podocyte adhesion for a healthy glomerulus
}

\author{
Rachel Lennon ${ }^{1,2,3}$ *, Michael J. Randles ${ }^{1,2}$ and Martin J. Humphries ${ }^{1}$ \\ ${ }^{\prime}$ Wellcome Trust Centre for Cell-Matrix Research, Faculty of Life Sciences, The University of Manchester, Manchester, UK \\ 2 Institute of Human Development, Faculty of Medical and Human Sciences, The University of Manchester, Manchester, UK \\ ${ }^{3}$ Department of Paediatric Nephrology, Manchester Academic Health Science Centre, Central Manchester University Hospitals NHS Foundation Trust, \\ Manchester, UK
}

Edited by:

Gavin lain Welsh, University of Bristol, UK

Reviewed by:

Hiroki Mizukami, Hirosaki University Graduate School of Medicine, Japan Shinichi Oikawa, Nippon Medical

School, Japan

Sanna Helena Lehtonen, University of Helsinki, Finland

\section{*Correspondence:}

Rachel Lennon, Wellcome Trust Centre for Cell-Matrix Research, The University of Manchester,

Michael Smith Building, Manchester M13 9PT, UK

e-mail: rachel.lennon@manchester. ac.uk
Podocytes are specialized epithelial cells that cover the outer surfaces of glomerular capillaries. Unique cell junctions, known as slit diaphragms, which feature nephrin and Neph family proteins in addition to components of adherens, tight, and gap junctions, connect adjacent podocyte foot processes. Single gene disorders affecting the slit diaphragm result in nephrotic syndrome in humans, characterized by massive loss of protein across the capillary wall. In addition to specialized cell junctions, interconnecting podocytes also adhere to the glomerular basement membrane (GBM) of the capillary wall. The GBM is a dense network of secreted, extracellular matrix (ECM) components and contains tissue-restricted isoforms of collagen IV and laminin in addition to other structural proteins and ECM regulators such as proteases and growth factors. The specialized niche of the GBM provides a scaffold for endothelial cells and podocytes to support their unique functions and human genetic mutations in GBM components lead to renal failure, thus highlighting the importance of cell-matrix interactions in the glomerulus. Cells adhere to ECM via adhesion receptors, including integrins, syndecans, and dystroglycan and in particular the integrin heterodimer $\alpha 3 \beta 1$ is required to maintain barrier integrity. Therefore, the sophisticated function of glomerular filtration relies on podocyte adhesion both at cell junctions and at the interface with the ECM. In health, the podocyte coordinates signals from cell junctions and cell-matrix interactions, in response to environmental cues in order to regulate filtration and as our understanding of mechanisms that control cell adhesion in the glomerulus develops, then insight into the effects of disease will improve. The ultimate goal will be to develop targeted therapies to prevent or repair defects in the filtration barrier and to restore glomerular function.

Keywords: podocyte, adhesion and signaling molecules, cell junction, extracellular matrix, nephrotic syndrome

\section{INTRODUCTION}

The glomerulus is a highly sophisticated organelle that performs selective filtration of circulating blood. With a diameter of between 110 and $280 \mu \mathrm{m}$ in humans (1), the glomerulus is a spherical bundle of capillaries contained by a cellular Bowman's capsule. The capillaries are lined by fenestrated endothelial cells and covered by specialized epithelial cells known as podocytes (Figure 1). Between the cell layers, there is a thick glomerular basement membrane (GBM) providing a structural scaffold to support the capillary wall. Endothelial cells and their associated glycocalyx (2), the GBM, and podocytes together form the glomerular filtration barrier, which allows free permeability to water and small solutes but prevents the loss of macromolecules or cells from the blood into the primary filtrate. Each human kidney contains approximately 1 million glomeruli, and they perform this selective filtration to generate a remarkable $180 \mathrm{l}$ of filtrate per day (3).

Glomerular disease is characterized by reduced barrier integrity with consequent loss into the urine of protein (proteinuria) and or blood cells (hematuria). Barrier dysfunction is characterized by flattening or effacement of podocyte foot processes, as visualized by electron microscopy (Figure 2). Causes of barrier disruption range from congenital disorders associated with genetic mutations to acquired disease linked to a range of inflammatory or metabolic disturbances, which may specifically target the glomerulus or be part of a wider systemic illness, such as diabetes mellitus. Persistent glomerular dysfunction with proteinuria leads to chronic and ultimately end-stage kidney disease with a rapidly accelerating impact on worldwide healthcare costs. Dialysis and transplantation therapies are not globally accessible and the risk of recurrent glomerular disease following transplantation can be as high as 30\% (4). There are currently limited therapies to slow the progression of glomerular disease and, therefore, a significant need to build our understanding about both normal glomerular function and the dysfunction associated with pathology.

The integrity of the glomerular filtration barrier depends on both cell-cell adhesion and cell-matrix adhesion, which have been predominantly investigated in podocytes, although undoubtedly critical for the glomerular endothelium. Cell-cell and cell-matrix adhesion receptors connect adjacent cells or matrix ligands to the cellular cytoskeleton, and they are vital conduits for the 


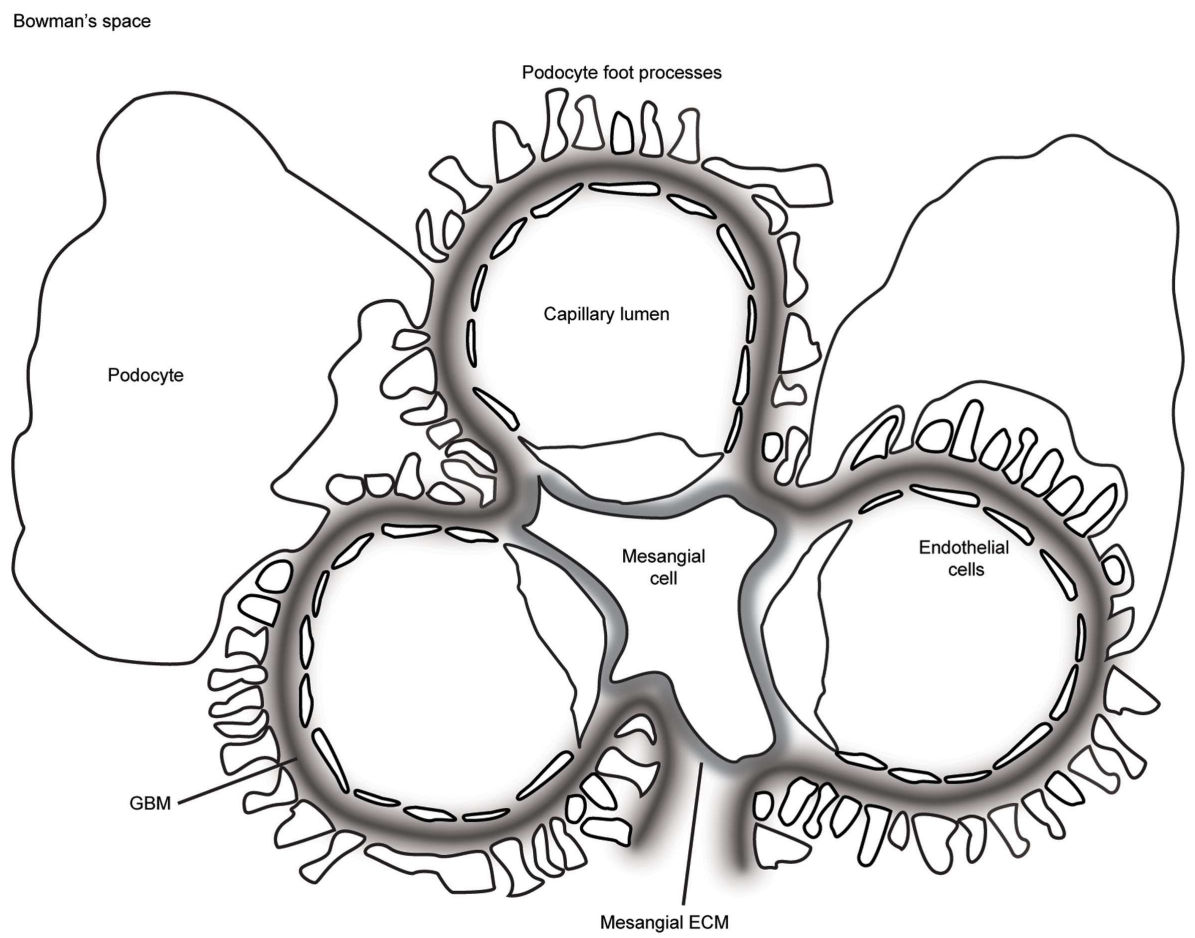

FIGURE 1 | A schematic representation of the glomerulus in cross-section. The glomerular capillaries are lined on the inside with fenestrated endothelial cells, which are attached to the glomerular basement membrane (GBM). Podocytes cover the outer aspect of GBM with large cell bodies and inter-digitating foot processes. Mesangial cells and their associated extracellular matrix (ECM) connect adjacent capillaries, and the capillary bundle is contained within Bowman's capsule. transmission of signals in and out of cells. These receptors are highly conserved in evolution and are a fundamental requirement for tissue development. The glomerular filtration barrier is a highly complex structure, and we require deep understanding to appreciate how the barrier is formed during development, regulated in health, and disrupted in disease. This review focuses on the importance of podocyte adhesion for a healthy glomerulus. Cell-matrix adhesion is introduced initially with a review of the glomerular extracellular matrix (ECM) and our understanding about cell adhesion to ECM ligands. Cell-cell adhesion follows with a review of the unique podocyte slit diaphragm. Finally, we discuss the prospects for therapy to target defects in adhesion for patients with glomerular disease.

\section{THE GLOMERULAR EXTRACELLULAR MATRIX}

Extracellular matrix is essential for multicellular life providing a structural scaffold with appropriate mechanical properties to support adjacent cells (5). It comprises a complex network of glycosaminoglycans and fibrous proteins, which are synthesized and secreted by cells. Podocytes and glomerular endothelial cells adhere to ECM networks via cell surface receptors. This cell-ECM interface forms a signaling platform that controls all aspects of cell fate decisions, including shape, growth, differentiation, and survival $(5,6)$. In addition to this signaling platform, the ECM modulates cell-cell signaling by sequestering secreted growth factors and cytokines, forming reservoirs for controlled release (5).
Basement membranes are condensed sheets of ECM with a supramolecular assembly built around two major networks of laminin and collagen IV. In the glomerulus, ECM is organized as the GBM of the capillary walls and basement membrane of Bowman's capsule, in addition to the loose mesangial ECM between capillary loops (Figure 1). The mature GBM is thicker than most basement membranes (300-350 nm in humans), and it represents a fusion of two membranes, one derived from podocytes and the second from endothelial cells during glomerular development (7). The study of human glomerular disease led to the discovery of tissue-restricted isoforms of laminin and collagen IV in the mature GBM, and these are key components of this specialized extracellular niche $(8,9)$.

Laminins are self-assembling heterotrimeric glycoproteins (10, 11 ) and an absolute requirement for basement membrane formation $(12,13)$. All laminin heterotrimers contain $\alpha, \beta$, and $\gamma$ chains. The trimeric protein has a cruciform shape with one long arm and three short arms and the short arms contain the amino terminal (LN) domains of the laminin heterotrimer. These short arms also form the nodes within the laminin network, exclusively via interactions between the chain specific LN domains (14-16). The long arms contain the globular (LG) domains with cell surface receptor binding sites (17-21).

The developing GBM contains laminin $\alpha 5 \beta 1 \gamma 1$ (laminin-511), but the mature GBM comprises predominately laminin-521. A complete laminin-521 network is the key for a functional GBM 

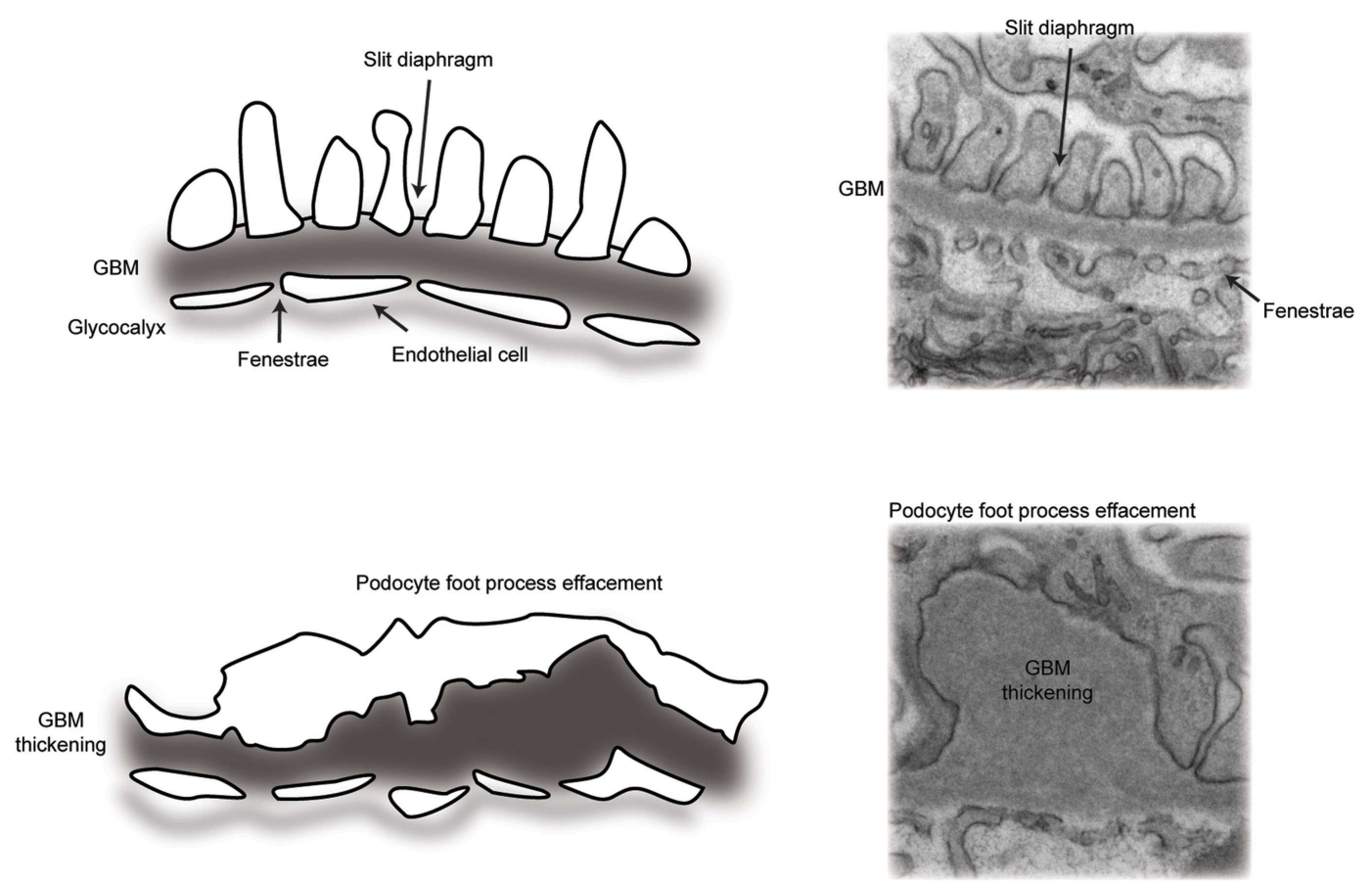

FIGURE 2 |A schematic representation of the glomerular filtration barrier. (Top panel) transmission electron micrograph and schematic of the normal architecture of the multi-layered glomerular filtration barrier. (Bottom panel) transmission electron micrograph and schematic of glomerular filtration barrier defects, including loss of slit diaphragms and podocyte foot process effacement, in addition to thickening of the glomerular basement membrane. as mutations in $L A M B 2$, the gene encoding the laminin $\beta 2$ chain, cause Pierson syndrome in human beings. Affected individuals have a spectrum of pathology dependent on the type of mutation with truncating mutations causing congenital nephrotic syndrome, microcoria, muscular hypotonia, and neurodevelopmental deficit $(22,23)$. Lamb2 mutations in mice are also associated with glomerular dysfunction. Mice with null mutations die after 3 weeks of age with severe proteinuria and neuromuscular defects (24). These animals have accumulation of ectopic laminin chains in the GBM, including $\alpha 1, \alpha 2, \alpha 3, \beta 1, \beta 3$, and $\gamma 2$; however, these chains do not compensate for the loss of the $\beta 2$ chain, possibly due to low expression or the absence of a complete laminin network (25). The theory that insufficient expression of laminin chains accounts for the observed lack of compensation is supported by the finding that podocyte overexpression of Lamb1 in Lamb2 null mice ameliorates proteinuria (26).

Unlike the laminin network, the collagen IV network is dispensable for basement membrane formation; however, it appears to be important for strength and stability (27). Collagen IV forms heterotrimers comprising three alpha chain combinations $(\alpha 1 \alpha 1 \alpha 2$, $\alpha 3 \alpha 4 \alpha 5$, or $\alpha 5 \alpha 5 \alpha 6$ ). Each alpha chain contains three distinct domains; an amino terminal $7 \mathrm{~S}$ domain rich in cysteines and lysines, which is essential for inter-chain crosslinking through disulfide bonds and lysine/hydroxylysine crosslinks; a long collagenous repeat domain, around 1400 amino acids in length; and a carboxy terminal non-collagenous domain (NC1) (28). A novel chemical bond, not previously identified in biomolecules, the sulfilimine bond $(-\mathrm{S}=\mathrm{N}-)$, was recently discovered in collagen IV.
This bond crosslinks lysine/hydroxylysine-211 and methionine-93 of adjoining protomers in the $\mathrm{NC1}$ domains of both collagen IV $\alpha 1 \alpha 1 \alpha 2$ and $\alpha 3 \alpha 4 \alpha 5$, which may provide additional resistance of the network to mechanical strain (29). Furthermore, peroxidasin, an enzyme found in basement membranes, catalyzes the formation of the sulfilime bond (30), and in ground breaking recent work, ionic bromide was shown to be a cofactor required for peroxidasincatalyzed formation of the sulfilimine crosslinks in collagen IV networks (31), thus describing the first known essential function for bromine in animals.

From the capillary loop stage of glomerular development, the GBM comprises predominantly $\alpha 3 \alpha 4 \alpha 5$ networks of collagen IV, and as with laminin, the developmental collagen IV transition is critical for GBM maturation. Mutations leading to a reduction or absence of the $\alpha 3 \alpha 4 \alpha 5$ networks cause human Alport syndrome characterized by a renal phenotype of hematuria, proteinuria, and progressive renal failure $(28,32)$. The GBM in Alport syndrome has increased collagen IV $\alpha 1 \alpha 1 \alpha 2$, which is unable to compensate for the lack of the $\alpha 3 \alpha 4 \alpha 5$ network. As a consequence, the GBM develops splits and a typical basket-weave appearance, leading to speculation that mechanical strain cannot be tolerated perhaps due to fewer disulfide bonds in the $\alpha 1 \alpha 1 \alpha 2$ network relative to $\alpha 3 \alpha 4 \alpha 5$ and consequently a weaker GBM. This concept is further supported by the observation that reducing mechanical strain in the glomerulus with angiotensin-converting enzyme (ACE) inhibitors, which lower blood pressure as well as transcapillary filtration pressure, significantly delays disease progression in Alport syndrome (33-35). 
The laminin and collagen IV networks are indirectly linked via nidogens (36) and the heparan sulfate proteoglycans, perlecan (37,38), and agrin (39). Podocyte-specific deletion of agrin from the GBM resulted in a significant reduction in the negative charge associated with the barrier, however, alone or combined with knockout of perlecan, agrin deletion was not associated with proteinuria, therefore questioning the role of charge selection in glomerular filtration (40). Nidogen 1 and 2 are dumbbell-shaped proteins and bind to both laminin and collagen IV. Mice with knockout of either nidogen 1 or 2 are viable and have normal basement membranes. Deletion of both isoforms, however, causes perinatal lethality (41). This is consistent with a degree of redundancy in their ability to bind collagen IV and laminin. Surprisingly, the GBM has a normal appearance even in the double (Nid-1, Nid-2) knockout. This suggests that nidogen is dispensable for the formation of the GBM, but again it may be required for the GBM to resist mechanical strain. Taken together, it is likely that agrin, perlecan, and nidogens are important for overall basement membrane strength by contributing to the crosslinking of the collagen and laminin networks to each other and to the cell surface.

While these and other investigations detail the composition of the glomerular ECM, it has been more challenging to elucidate the relative position of ECM proteins in the GBM. However, a systematic analysis of the spatial arrangement of ECM components within basement membranes, with respect to each other and to their cell-adhesion receptors, was recently performed using super resolution microscopy (42). This investigation found two separate laminin networks, one produced by podocytes the other produced by endothelial cells. The collagen IV $\alpha 3 \alpha 4 \alpha 5$ network was distributed along the center of the GBM alongside nidogen, consistent with its putative crosslinking function. The human GBM is approximately twofold thicker than the mouse GBM, and interestingly, this study found increased thickness of the human collagen IV a3a4a5 network, and potentially, an additional layer of laminin-521 closer to the center of the GBM (42).

Thus, candidate-based investigations of the glomerular ECM have significantly advanced our understanding about key components. However, more recently unbiased, global approaches have shown that the glomerular ECM is a highly complex extracellular niche. In our own proteomic analysis of human glomerular ECM, we identified 144 structural and regulatory ECM proteins and found that more than $50 \%$ were expressed in the GBM (43). Together with the analysis of cell-derived ECM produced by glomerular cells in culture, we found a common core of highly connected and clustered ECM proteins, which may be important for ECM assembly (44). Overall, the glomerular ECM is a complex scaffold of interacting proteins, which are likely to be highly dynamic and are unique in order to support the complex function of the glomerular filtration barrier.

\section{PODOCYTE ADHESION TO THE GBM}

In order to adhere to the GBM, podocytes and endothelial cells utilize transmembrane adhesion receptors and the cell-matrix adhesion of podocytes was recently reviewed elsewhere (45). Adhesion receptors contain extracellular domains, which can bind to specific ECM proteins and intracellular domains that recruit effector proteins and link adhesion receptors to the cell cytoskeleton
(Figure 3). A major family of proteins responsible for cell-ECM adhesion is the integrins.

Integrins are $\alpha \beta$-heterodimers that propagate signals from within the cell to the immediate extracellular environment in addition to outside-in signaling. All integrins link to the actin cytoskeleton, with the exception of $\alpha 6 \beta 4$, which links to intermediate filaments (6). Conformational changes in these receptors are central to the regulation of integrin receptor activity. Integrins adopt either a low affinity bent conformation, a primed or active high affinity extended conformation, or a ligand occupied state (46). Integrins form 24 different $\alpha \beta$ combinations (6), which have differing affinities for ECM ligands and also have differential recruitment of proteins to their cytoplasmic domains (47). Laminin-binding integrins include $\alpha 1 \beta 1, \alpha 2 \beta 1, \alpha 3 \beta 1, \alpha 6 \beta 1$, $\alpha 10 \beta 1$, and $\alpha 7 \beta 1$, and the collagen binding integrins are $\alpha 1 \beta 1$, $\alpha 2 \beta 1, \alpha 10 \beta 1, \alpha 11 \beta 1$, and $\alpha \mathrm{X} \beta 2$ (48).

Upon integrin engagement of the ECM, there is integrin clustering and activation. Integrins lack intrinsic enzymatic activity; therefore, in order to propagate signals into the cell, active integrins must recruit a number of adaptor and effector proteins into sites known as focal adhesions. At least 232 protein components are recruited to adhesion complexes in a cell type and context dependent manner, demonstrating the potential for adhesion signaling to bring about different cellular outcomes (49). In addition, global analyses of adhesion complexes using mass spectrometry suggest an even larger number of proteins may be recruited to focal adhesions (50-52). Examples of the groups of proteins recruited to sites of active integrins are adaptors, actin remodeling proteins, signaling proteins, GTPase regulators including guanine-nucleotide exchange factors (GEFs) and GTPase activating proteins (GAPs) in addition to numerous serine, threonine and tyrosine kinases, and phosphatases. This signaling nexus controls all aspects of cell fate and so does not just act as a mere anchoring point for cell attachment but also a signaling hub to alter cell behavior. Furthermore, integrin association and cross talk with other transmembrane receptors such as syndecans increases the potential for regulation of integrin-mediated adhesion $(53,54)$.

The $\alpha 3 \beta 1$ heterodimer is the most highly expressed integrin on the podocyte cell surface, and is thought to be the most important link between the podocyte and the GBM (55-57). Homozygous mutations in ITGA3, the gene encoding integrin $\alpha 3$, in humans leads to congenital nephrotic syndrome, interstitial lung disease and epidermolysis bullosa (58) with defects in the GBM. In addition, a mutation in ITGA3 causing a gain of glycosylation and preventing $\alpha 3 \beta 1$ dimer formation causes fatal interstitial lung disease and congenital nephrotic syndrome (59). This phenotype is recapitulated in mice lacking the integrin $\alpha 3$ subunit, which die within the first day of life due to developmental defects in the kidneys and lungs, including loss of specialized podocyte morphology and thickened irregular GBMs (60). Moreover, podocyte-specific deletion of Itga3 in the mouse also resulted in a disorganized GBM with thickening and protrusions and an inability of podocytes to form mature foot processes (61). Human mutations affecting integrin- $\beta 1$ have not been described, to date, and this may be due to embryonic lethality since integrin- $\beta 1$ forms at least 12 heterodimers. However, the role of this integrin has been studied with podocyte-specific deletion of Itgb1 in the mouse. This resulted 


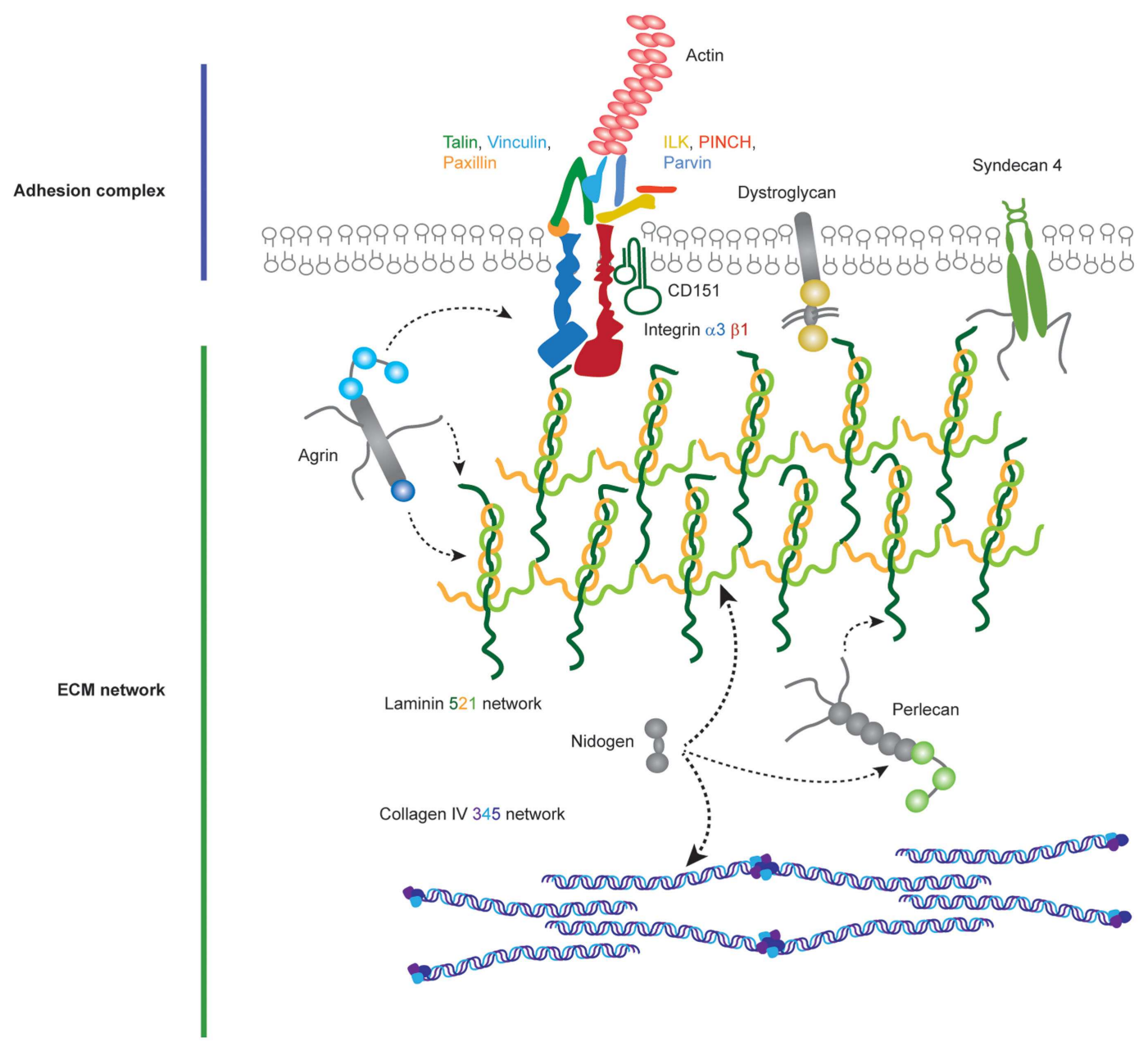

FIGURE 3 | Molecular components of the podocyte cell-matirx interface. Podocytes adhere to the underlying GBM using transmembrane adhesion receptors. The laminin-binding integrin $\alpha 3 \beta 1$ and the associated tetraspannin CD151 are highly expressed on the podocyte cell surface, in addition to adhesion receptors for other ECM ligands. Adhesion complexes form when activated integrins recruit adaptor, scaffold, and signaling proteins to their cytoplasmic tails. Integrins link to the actin cytoskeleton via two major axes; talin, vinculin, paxillin and integrin-linked kinase (ILK), PINCH, parvin. Podocytes attach to an ECM network containing laminin-521 networks, collagen IV $\alpha 3 \alpha 4 \alpha 5$ networks, agrin, perlecan, and nidogen. in a severe phenotype of proteinuria from birth and renal failure by 3 weeks featuring both glomerular and tubular pathologies $(62,63)$.

The tetraspannin CD151 binds tightly to integrin $\alpha 3 \beta 1$ (64) and humans with mutations in CD151 develop hematuria and proteinuria progressing to end-stage kidney disease in addition to pretibial epidermolysis bullosa, sensorineural deafness, and $\beta$ thalassemia minor (65). In mice, deletion of $C d 151$, both globally and specifically in podocytes, caused early proteinuria with abnormalities of the GBM loss of podocyte foot processes, glomerulosclerosis, loss of podocytes, and renal failure. This phenotype, however, is dependent on the genetic background of the mice, with Cd151-knockout mice on the FVB background displaying the pathological phenotype $(61,66,67)$. It is hypothesized that CD151 increases the strength of podocyte adhesion to the GBM via integrin $\alpha 3 \beta 1$ engagement with laminin-521. Cd151-knockout mice on the C57BL/6 background do not spontaneously develop renal failure but when challenged with induced hypertension, they develop significant proteinuria. Furthermore, treatment of the susceptible Cd151-knockout FVB strain with ACE inhibitors ameliorated progression of renal failure. In addition to in vivo experiments, in vitro experiments showed that podocytes lacking CD151 lose their resistance to shear stress when cultured on laminin (67). This evidence supports a crucial role for integrin $\alpha 3 \beta 1$ as a major adhesion receptor, and in combination with CD151, a complex necessary to withstand mechanical forces within the glomerulus.

The laminin-binding integrin $\alpha 6 \beta 4$ may also be the key for the development and maintenance of the glomerular filtration barrier. Human mutations in ITGB4 have been described and associated with junctional epidermolysis bullosa and pyloric atresia $(68,69)$. In one of these patients, there was coincident nephrotic range proteinuria and the study demonstrated reduced expression of integrin- $\beta 4$ in podocytes; however, the possibility of an alternative genetic explanation for the glomerular dysfunction in this 
case remains possible. Integrin $\alpha v \beta 3$ has also been implicated in glomerular dysfunction $(70,71)$. This fibronectin receptor was shown to be activated following the induction of urokinase receptor (UPAR) signaling leading to increased podocyte motility and activation of GTPases. In a subsequent study, the same team identified soluble uPAR as a potential pathogenic mediator of disease in nephrotic syndrome associated with focal segmental glomerulosclerosis (FSGS) where there was also activation of integrin- $\beta 3$ (72). These studies raise the possibility that abnormal integrin activation in the podocyte alters cell motility and this signaling pathway could potentially be targeted therapeutically.

In addition to the integrin family of adhesion receptors, transmembrane heparan sulfate proteoglycan receptors, such as the Syndecan family, are key regulators of cell-ECM interactions (54). Cooperation of integrins and syndecans in adhesion formation has been shown on a variety of ECM ligands including fibronectin, vitronectin, and laminin (73-76). Syndecans regulate intergrin trafficking to the cell surface (77), a process used by cells to regulate adhesion formation and disassembly (78-80). In addition to modulating integrin dynamics, syndecans facilitate growth factor binding to their receptors $(81,82)$. In podocytes null for EXT1, a key molecule in herparan sulfate glycosaminoglycan assembly, adhesion complexes were reduced in size, the actin cytoskeleton was rearranged, and cell surface syndecan 4 upregulated (83). However, mice null for EXT1 specifically in podocytes do not develop significant proteinuria, despite some podocyte abnormalities, including a degree of foot process effacement (84). In podocytes, autocrine signaling by the soluble vascular endothelial growth factor receptor, sFLT1, also causes actin rearrangements and this is associated with phosphorylation of both syndecan 1 and 4 within their EFYA motifs (85). Thus, there is accumulating evidence that syndecans contribute to cell-matrix adhesion and signaling in podocytes.

Dystroglycan is a cell surface adhesion receptor and comprises a highly glycosylated extracellular $\alpha$-dystroglycan subunit, which can bind to laminins, and a non-covalently linked intracellular $\beta$-dystroglygan subunit that links to the actin cytoskeleton via an interaction with utrophin $(86,87)$. Dystroglycan is expressed by podocytes (88) and the expression pattern is altered in glomerular pathologies $(89,90)$. Therefore, it seemed likely that dystroglycan was important for podocyte adhesion; however, defective glycosylation of $\alpha$-dystroglycan, which abrogates $\alpha$-dystroglycan-laminin interactions does not cause proteinuria, only mild podocyte foot process effacement (91). Furthermore, podocyte-specific deletion of dystroglycan in mice caused only mild GBM thickening (92). These data suggest that dystroglycan is not a critical adhesion receptor in podocytes.

\section{FOCAL ADHESION COMPLEXES}

A number of proteins link integrins to the actin cytoskeleton and form focal adhesions (Figure 3). One such is talin-1, a $270 \mathrm{kDa}$ protein comprising an N-terminal globular head and flexible rod domain. The head domain contains a FERM domain with binding sites for the integrin- $\beta$ subunit cytoplasmic tail, F-actin, focal adhesion kinase (FAK), and PIPK $1 \gamma 90$. The rod domain contains an additional binding site for integrin, actin binding sites, and multiple vinculin binding sites, and this domain can also bind to RIAM (93). Finally, the C-terminal domain contains helices responsible for talin dimerization. Binding of talin to the cytoplasmic tail of $\beta$-integrins triggers a conformational change in the extracellular domain of integrins, which amplifies the affinity of the integrin for the ECM. Talin dependent recruitment of further proteins to active integrins causes the consequent formation of focal adhesions (94). Talin-1 expression in podocytes is required for the specialized actin morphology of foot processes. Podocyte-specific $T \ln 1$-knockout mice develop proteinuria and die within 10 weeks. These mice, however, did not have major defects in integrin $\beta 1$ activation or podocyte adhesion. Nevertheless, the actin cytoskeleton was perturbed, and there was podocyte foot process effacement. These data show that talin-1, a protein known to be important in adhesion formation and linkage to the actin cytoskeleton in vitro, is a key player in relaying signals from integrins to the actin cytoskeleton in podocytes in vivo (95).

Another key adaptor protein involved in integrin-mediated adhesion complex formation is vinculin, a $123 \mathrm{kDa}$ protein recruited by talin to focal adhesions and capable of binding to the actin cytoskeleton (96). Vinculin comprises an N-terminal head, proline rich neck, and a C-terminal tail domain $(97,98)$. Cytoplasmic vinculin assumes an autoinhibited inactive conformation (99) and following talin recruitment, vinculin undergoes a conformational change revealing an open active state (100). Vinculin is a force regulator and when extended by forces applied through actin, there is subsequent recruitment and release of focal adhesion proteins (101). This conformational change allows vinculin to directly interact with a number of proteins including $\alpha$-actinin, Arp2/3, actin, and paxillin $(102,103)$. The vinculin head domain modulates integrin clustering, whereas the tail domain links to actin. Considering vinculin is an important link between integrins and the actin machinery, this protein may have a key role in the force sensing by podocytes via integrin $\alpha 3 \beta 1$.

Paxillin is another component of focal adhesions and it acts as a scaffolding protein. It contains multiple protein-binding modules, many of which are regulated by phosphorylation. It localizes to focal adhesions through phosphorylation of its C-terminal LIM domains $(104,105)$. Paxillin is an important molecular adaptor; its $\mathrm{N}$-terminus controls most of its signaling activity that provides docking sites for vinculin, FAK, Src, and Crk. Paxillin is recruited to focal adhesion by talin (106) and brings about spatiotemporal control of Rho family small GTPases by recruiting numerous GEFs and GAPs (107).

Another highly studied focal adhesion protein is FAK. FAK is non-receptor tyrosine kinase, recruited to focal adhesions by talin and paxillin (108). FAK has a number of roles at focal adhesion sites, including recruitment of p130Cas, Crk1/2, and Src family kinases (109). Global deletion of FAK in mice is lethal in embryogenesis, causing a profound migration defect (110). The importance of FAK in podocytes was highlighted by the observation that FAK is phosphorylated upon podocyte injury (111). Surprisingly, podocyte-specific deletion of FAK in mice leads to a normal phenotype; however, these mice are protected from proteinuria and podocyte injury after experimental podocyte insults (111). Additionally, podocyte injury was reduced when a FAK inhibitor was administered in a mouse model of glomerular injury (111). A role for FAK has also been found in Alport syndrome where ectopic 
laminins, $\alpha 1$ and $\alpha 2$, accumulate in the GBM. Laminin $\alpha 2$ caused phosphorylation of FAK at Y397, and this phosphorylation was associated with upregulation of the proteases MMP 9 and 10 and GBM defects (112). FAK inhibition reduced proteinuria, MMP levels, and GBM defects (112). These data, therefore, support a role for FAK in glomerular dysfunction.

Integrin-linked kinase binds directly to the integrin $\beta 1$ cytoplasmic tail and is important for signal transduction at adhesion sites (113). ILK was originally identified as a kinase, but increasing evidence suggests that is a pseudokinase (114-119). In fact, the C-terminal kinase homology domain of ILK mediates multiple protein-protein interactions at adhesion sites, including interactions with $\alpha / \beta / \gamma$-Parvin $(120,121)$. ILK also contains five ankyrin domains that mediate interactions with PINCH-1/2 (122-124). Kindlin 2 is another ILK interacting protein, which is expressed in podocytes, localizes to focal adhesions and through either ILK/PINCH/parvin or migfilin-filaminin interactions binds to the actin cytoskeleton (125-127). It is through this scaffolding role that ILK orchestrates focal adhesion signaling. The ILK/PINCH/parvin complex influences the actin cytoskeleton (128), in addition to negatively regulating cell contractility (129). Total loss of ILK or PINCH in mice is lethal in embryogenesis, due to failure in epiblast polarization $(128,130)$. The interaction between ILK and $\alpha$-parvin is required for kidney development. Mutations in ILK K220 disrupt $\alpha$-parvin binding and cause renal agenesis (131). Furthermore, a similar phenotype is observed when $\alpha$-parvin is genetically deleted in mice (131). Podocyte-specific loss of ILK in mice causes GBM defects, loss of slit diaphragms, and podocyte foot process effacement $(132,133)$. Moreover, ILK interacts with nephrin at podocyte cell junctions, suggesting that ILK is a potential link between cell-cell and cell-ECM adhesion signaling (132). Finally, increased expression of ILK is observed in a variety of glomerular diseases $(134,135)$. This evidence strongly supports an important role for ILK in adhesion signaling in podocytes.

Overall cell adhesion to the GBM occurs at a complex cellmatrix interface (Figure 4). A wide range of scaffolding proteins localize to focal adhesions and transmit information regarding the extracellular environment via recruitment of effectors including kinases, and GTPases. The cellular adhesome has been predominantly investigated in the context non-adherent cells or fibroblasts but less so for epithelial cells, and similar analyses in glomerular cells will help to build our understanding about the key cellular components that are involved in cell-matrix adhesion in the glomerulus. These studies have the capacity to identify unexpected and novel proteins at adhesion sites, which are considerably more complex than previously thought.

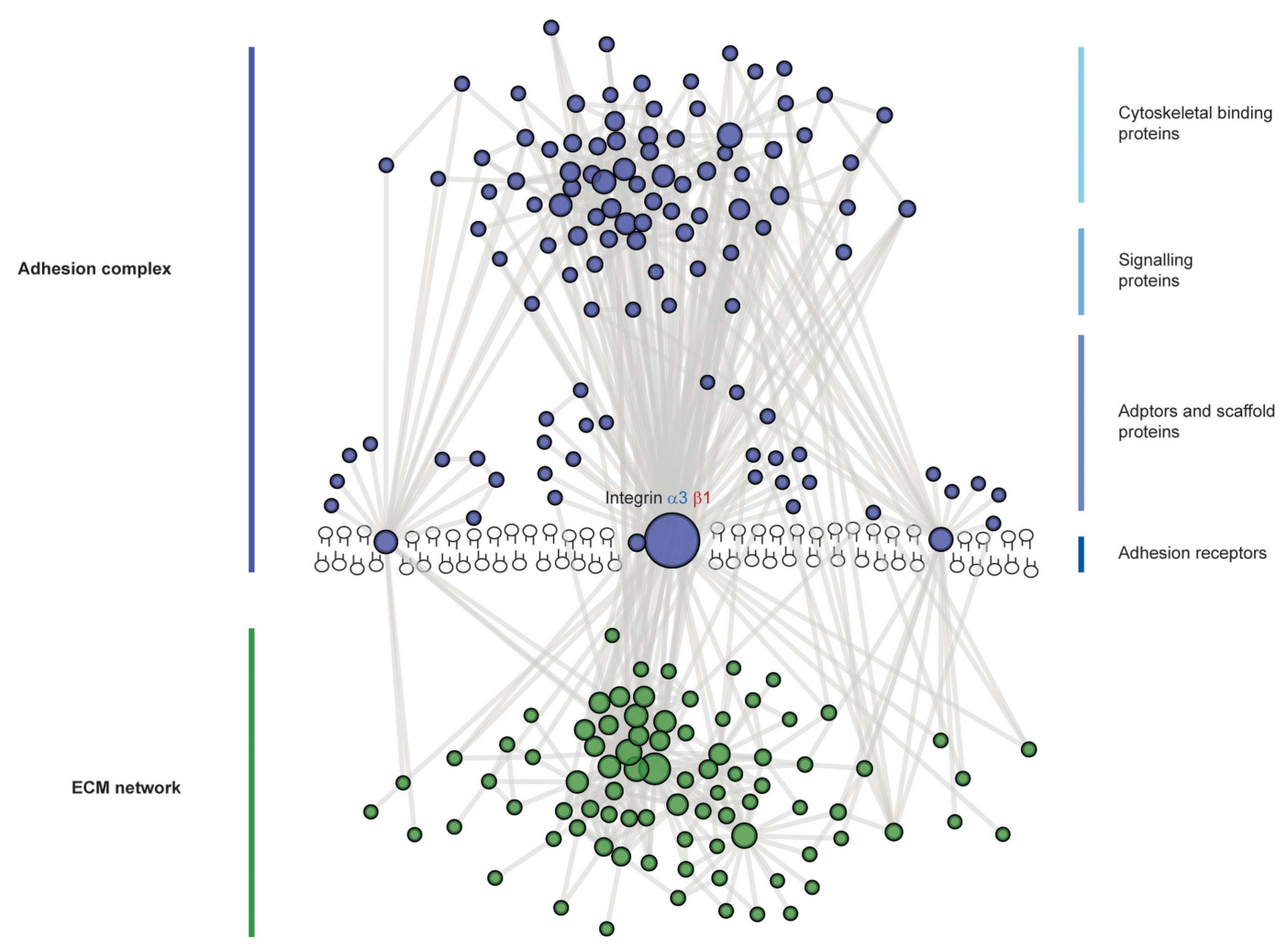

FIGURE 4 | The complexity of adhesion signaling, a protein-protein interaction view. A predicted protein-protein interaction network of adhesion signaling complexes in podocytes. Nodes represent proteins and lines between nodes represent experimentally derived protein-protein interactions. Extracellular matrix (ECM) proteins are green in color and adhesion signaling proteins are blue in color.
Integrins do not have intrinsic enzymatic activity; however, through conformational changes, integrins can recruit tens to hundreds of different proteins to adhesion sites. These adhesion sites are hubs for cellular signaling, controlling all aspects of cell fate. Adhesion signaling is determined by the composition and physical properties of the extracellular matrix. 


\section{ADHESION AT THE PODOCYTE SLIT DIAPHRAGM}

The junction between adjacent podocyte foot processes is termed the slit diaphragm and it is visible by electron microscopy as an electron dense structure close to the GBM. This specialized junction is thought to connect the entire length of adjacent foot processes providing a structural component to the filtration barrier. From early ultrastructural studies, a zipper-like substructure was described where protein bridges emanating from the podocyte plasma membrane link to a central filament in a lattice arrangement with rectangular pores (136). The calculated cross-sectional dimensions of these pores was $4 \times 14 \mathrm{~nm}$, approximately the size of an albumin molecule, and therefore, consistent with the observations from tracer studies using ferritin and dextrans that the slit diaphragm contributed significantly to the retention of macromolecules within the circulation $(137,138)$. Following these seminal ultrastructural and tracer studies was the discovery of the first unique slit diaphragm protein nephrin by positional cloning of the gene in congenital nephrotic syndrome of the Finnish type and leading, to further refinement of the zipper-like model of the podocyte cell junction $(139,140)$. More recent ultrastructural studies have used scanning electron microscopy to describe circular and ellipsoidal pores in the central region of the slit diaphragm, with a mean diameter of $12.1 \mathrm{~nm}$ (141). Interestingly, the same study demonstrated an increase in the size of some of these pores with proteinuria, perhaps providing an explanation for the increased transit of macromolecules across a defective filtration barrier.

Many studies have also shown that the architecture of the podocyte changes dramatically in human glomerular disease with flattening of the actin-rich foot processes and loss of slit diaphragms. Similar changes are observed in animal studies of puromycin aminonucleoside (PAN)-induced nephrotic syndrome or nephrosis (142). While these dramatic morphological changes are associated with a profound barrier defect, remarkably these changes seem to completely reverse especially in the subset of patients with nephrotic syndrome who respond to treatment with glucocorticoids.

\section{COMPONENTS OF THE PODOCYTE SLIT DIAPHRAGM}

The first junctions to form in podocytes are apical and have been described as tight junctions (143). During glomerular development, the junctional complexes descend toward the GBM and widen to become the mature slit diaphragm. These are highly specialized and unique junctions and many studies have identified components associated with more classical types of cell junctions. The zona occludens protein (ZO-1) was one of the first proteins found to localize to podocyte foot processes using immunogold labeling and electron microscopy (144). Using immunostaining of murine podocytes in culture and rat glomeruli, podocyte cell junctions were also shown to contain classical components of adherens junctions including cadherin-3 and $\alpha-, \beta$-, and $\gamma$-catenins (145). The tight junction components JAM-A, occludin, and cingulin were also found to be associated with slit diaphragms (146) and the same study reported that PAN nephrosis increased the expression of these tight junction components. There is also a report of the gap junction protein connexin- 43 localizing to the podocyte slit diaphragm, and it was found to be upregulated in the early phase of PAN nephrosis (147). Taken together, these findings suggest, not surprisingly, that there is context-dependent composition of these junctions.

In addition to components associated with other cell junctions, the slit diaphragm also contains unique proteins (Figure 5). Nephrin and the homologs Neph-1, Neph-2, and Neph-3 are known members of this cell junction and are comprehensively reviewed elsewhere (148). They are members of the immunoglobulin superfamily of cell-adhesion receptors and are involved in the development of specialized junctions in neurons and at the slit diaphragm (148). Orthologs of these proteins are expressed in Drosophila nephrocytes (149), which have nephrocyte diaphragms structures with very similar composition to the mammalian slit diaphragm (150). Interestingly, birds lack nephrin and Neph-3 but do form slit diaphragm-like structures (151). Further back in evolution, Caenorhabditis elegans expresses the orthologs SYG-1 (Neph1) and SYG-2 (nephrin), and these are required for synapse formation and specificity. Investigation of the crystal structures of these orthologs revealed SYG-1 homodimers with a conserved binding interface and an unusual, angled geometry in the heterophillic SYG1/2 complex (152). The crystal structures of nephrin and Neph homologs remain unresolved; however, there is some evidence for homophilic nephrin interactions. These interactions were detected using recombinant nephrin protein and surface plasmon resonance, and they were increased in the presence of calcium (153).

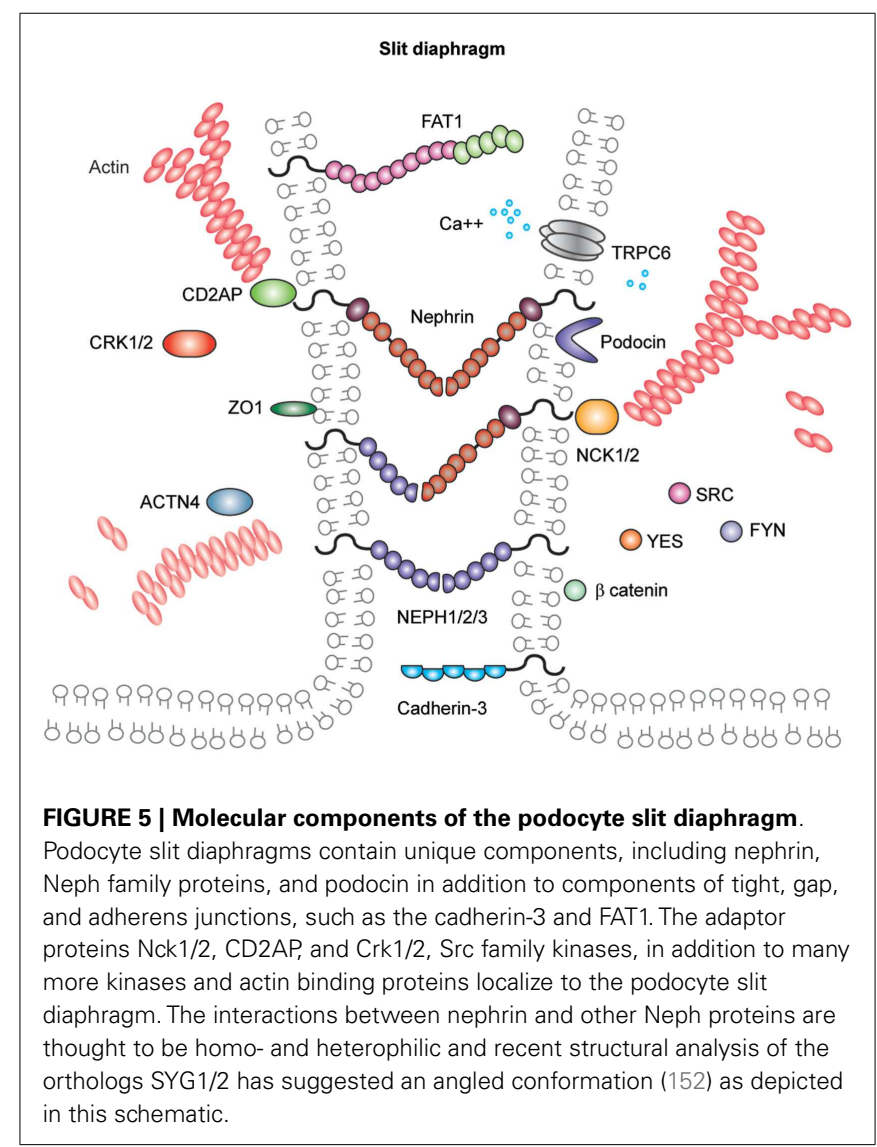


Nephrin and Neph-1 are requisite components of the slit diaphragm. Mutations in nephrin cause human congenital nephrotic syndrome (139), which is most common in Finland, although many mutations have now been described in individuals with later onset of disease and from a diverse ethnic background (154). Infants require albumin infusions to maintain intravascular volume and ultimately proceed to removal of their kidneys prior to dialysis and transplantation. This disease phenotype is mimicked in the mouse where deletion of Nphs1 leads to early massive proteinuria and the mice die within $24 \mathrm{~h}$. Ultrastructural analysis of their glomeruli has revealed the absence of slit diaphragms and foot process effacement (155). Neph1 deletion in mice is also associated with perinatal lethality with proteinuria and podocyte foot process effacement (156). As yet, no human mutations in NEPH1 have been described but it is more widely expressed than nephrin, and therefore, mutations may be incompatible with life.

Other notable members of the slit diaphragm complex include podocin, a stomatin family protein that is also mutated in patients with early onset nephrotic syndrome (157). Podocin is important for the recruitment of proteins to the slit diaphragm complex and for facilitating signaling (158). CD2AP is an adaptor protein and its role in maintaining the integrity of the filtration barrier was first described in mice (159) and more recently in human disease (160). CD2AP and CIN85 appear to be important for the balance of receptor tyrosine kinase signaling in podocytes (161). FAT atypical cadherin-1 has also been shown to regulate barrier formation and mice lacking this component have significant glomerular defects, in addition to eye and brain abnormalities (144).

The protein complex at the slit diaphragm includes the components that make the connections between adjacent podocyte foot processes in addition to the more dynamic network of proteins that assemble intracellularly (Figure 6). To identify novel components of this complex, unbiased approaches with mass spectrometry have led to the discovery of proteins including IQGAP (162). These global analyses will continue to assist in the identification of more unexpected components of these junctions as methods to isolate and analyze the junctions improve. To give an indication of the scale of the components, a recent bioinformatic analysis of the cadhesome has predicted an assembly of 170 components many of which may be cell type and context specific (163).

\section{SIGNAL TRANSDUCTION AT THE SLIT DIAPHRAGM}

Over the past 16 years since the discovery of nephrin, a growing number of proteins have been linked to signaling at the slit diaphragm and there are several recent, comprehensive reviews $(164,165)$. Phosphorylation of nephrin and Neph family proteins is the key to signal transduction. Tyrosine phosphorylation by Src family kinases initiates a signal cascade and indeed the deletion of Fyn resulted in barrier dysfunction (166). Phosphorylation by Fyn leads to the recruitment of a number of proteins including the adaptor proteins Nck1/2 (167, 168), Crk1/2 (169), CrkL (170), and Grb2 $(171,172)$ in addition to PI3-kinase $(173,174)$. Following recruitment, Nck binds phosphorylated nephrin and leads to actin reorganization via the actin nucleation factor N-WASP (175). The receptor Robo 2 also links to Nck and is expressed in podocytes (176). This receptor was found to inhibit actin reorganization and it appears to negatively regulate signaling via nephrin and Nck therefore to reduce podocyte foot process effacement. Crk is recruited to phosphorylated nephrin via p130Cas and deletion of Crk1/2 attenuated podocyte foot process effacement in a glomerular injury model (169). The p85 regulatory subunit of P13-kinase also interacts with nephrin leading to downstream activation of

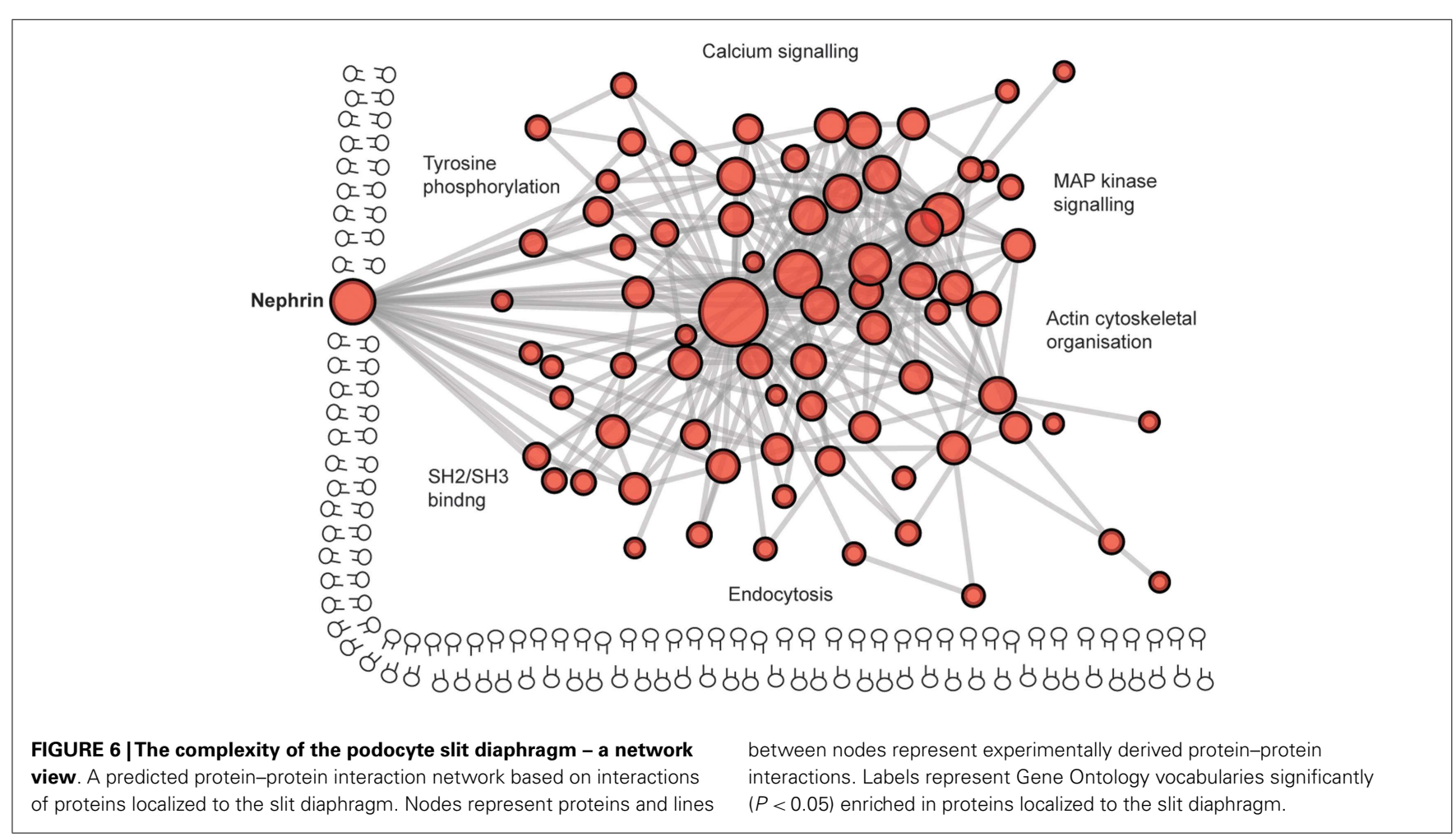


Akt (173) and subsequently to actin reorganization (174). Demonstrating the importance of signaling via Akt, deletion of the Akt2 isoform was associated with barrier dysfunction (177) and Akt phosphorylation in podocytes follows insulin signaling (178) and is also linked to mTOR signaling (177).

Regulation of the podocyte actin cytoskeleton is, therefore, the key to maintaining barrier integrity and actin reorganization in podocytes is likely to relate directly to the dramatic podocyte foot process effacement, which is seen across the spectrum of disease. The actin crosslinking protein alpha-actinin- 4 has been associated with human nephrotic syndrome and mutations in ACTN4 are associated with adult onset FSGS (179). Here, the mutated alphaactinin-4 protein binds filamentous actin more strongly than the wild type protein, indicating that actin regulation is important for normal podocyte function. Another class of actin regulators is the GTPases, which in turn are regulated by GEFs, GAPs, and GDIs. Podocyte-specific deletion of the GTPase RhoA did not result in a barrier defect (180); however, activation of RhoA has been described in a number of glomerular injury models in addition to human disease including mutations in the formin INF2, leading to the commonest cause of adult onset FSGS (181). A number of studies have now investigated the role of Racl in podocytes, which is required for lamellipodia formation. Racl is not essential for glomerular development but overexpression leads to barrier dysfunction either with constitutive activation of Rac1 (182) or RhoGDI-alpha knockout (183). However, a number of studies have also shown that $\operatorname{Racl}$ is protective $(170,184)$ and it is likely that a fine balance is required. The GTPase CDC42 is linked to the formation of filopodia and its absence results in early barrier dysfunction $(180,185)$ and this may be due to links with apicalbasal polarity proteins, which are also required for slit diaphragm formation (186).

The dynamic regulation of this specialized cell junction undoubtedly requires quality control and recycling of components, and it was recently shown using rat glomeruli that the turnover rates of slit diaphragm proteins was high and was regulated by atypical protein kinase C (aPKC) (187). Accordingly, the endocytic pathway components dynamin, synaptojanin, and endophilin have been shown to be important for maintaining barrier function (188). The correct localization of proteins is also the key, and nephrin localization at the plasma membrane requires the endocytic protein Myolc (189). The long-tailed myosin, Myo1E, may also contribute to endocytosis in podocytes $(190,191)$. The role of calcium signaling at the slit diaphragm is also important and mutations in the transient receptor potential cation channel TRPC6 have been associated with adult onset FSGS $(192,193)$.

There are still many research questions to address in order to understand how the specialized slit diaphragm is formed during development, regulated in health, and disrupted in disease. Chemical and mechanical factors in the microenvironment are likely to be the key, and although the barrier regulation by growth factors has not been discussed here, there is growing evidence for the important roles of vascular endothelial growth factor (VEGF-A) (85) and insulin (178). Regarding mechanical cues, it would seem likely that filtration forces contribute to the regulation of the barrier. The molecules spanning the slit diaphragm are directly exposed to force and it would be intriguing to determine whether some of these components respond to force in a similar manner to VE cadherin, which was recently investigated using a tension biosensor and shown to stretch in endothelial cells exposed to sheer stress (194). Understanding some of these basic mechanisms of regulation will be required to identify specific therapeutic strategies to maintain or restore glomerular function.

\section{PROSPECTS FOR ADHESION-BASED THERAPY FOR GLOMERULAR DISEASE}

Cell adhesion is clearly important to maintain normal barrier function but what are the prospects for adhesion-based therapies? Current therapies for glomerular disease include both immunomodulation and inhibition of the renin-angiotensinaldosterone (RAAS) signaling pathway. RAAS pathway inhibition with ACE inhibitors and angiotensin receptor blockers (ARBs) are thought to act primarily by reducing glomerular hydrostatic pressure. Immunomodulatory drugs such as glucocorticoids and calcineurin inhibitors were initially thought to act via immune cells; however, these agents may also directly target the podocyte (195). The effects of existing and efficacious therapies on podocyte adhesion have not been formally tested, although there are some intriguing observations. Spironolactone (an inhibitor of aldosterone) was shown to reduce the urinary excretion of podocytes in a rat model of diabetic nephropathy (196), and this presumed reduction in podocyte detachment was associated with upregulation of integrin $\alpha 3$. Furthermore, in a study of human podocytes in culture, the glucocorticoid dexamethasone was shown to increase nephrin expression (197).

The manipulation of integrin activation as a possible route to therapy has been suggested in a series of recent studies. Activation of integrin- $\beta 3$ has been implicated in the pathogenesis of nephrotic syndrome associated with FSGS. In a subset of patients with FSGS, there is strong evidence for the role of a circulating and disease-causing factor, which can lead to recurrence of primary disease in transplanted kidneys. Soluble urokinase receptor (suPAR) was identified as a pathogenic factor leading to activation of integrin- $\beta 3$ in mouse models and human disease (72) leading to the suggestion that therapy for this condition could involve inhibition of the suPAR-integrin- $\beta 3$ interaction by the use of small molecule inhibitors. Indeed, a beneficial effect of such an inhibitor has been shown in experimental glomerulonephritis (71).

Inactivation of integrin- $\beta 1$ subunit has also been proposed, a mechanism of disease in patients with FSGS (198). Five patients with FSGS and positive B7-1 (CD80) immunostaining in glomeruli were treated with the B7-1 inhibitor Abatacept. This treatment was associated with a significant reduction in proteinuria in patients, otherwise resistant to standard therapies. While these discoveries suggest a role for manipulating signaling by adhesion receptors, given the myriad roles of these receptors, the challenge will be to target the treatment appropriately (199).

Disease-associated changes in ECM are likely to trigger a number of intracellular signaling events to influence cell adhesion. By understanding more about the pathways involved, it may be possible to target these therapeutically. In Alport syndrome, the primary molecular defect in the ECM is absence of the collagen IV- $\alpha 3 \alpha 4 \alpha 5$ network. Therefore, delivery of the wild type gene could be a potential future therapy and proof of principle was 
recently shown by the induction Col4a3 in Col4 a3-/- mice (200). Induced expression of collagen IV- $\alpha 3$ slowed disease progression and improved survival providing significant optimism for the prospects of gene therapy; however, the major issue will be gene delivery to the podocyte. Abnormal outside-in signaling from the ECM could also be targeted, and in another study of Alport syndrome, inhibition of FAK in mice led to partial restoration of the GBM and a reduction in proteinuria (112).

Manipulating signaling from slit diaphragm adhesion receptors may also be a future therapeutic strategy. In patients with NPHS1 mutations, nephrin is thought to accumulate in the endoplasmic reticulum and the hypothesis that chemical chaperones would export nephrin to the plasma membrane was tested with sodium-4 phenylbutyrate in HEK293 cells. Several mutant nephrin proteins were rescued using this strategy, and there was evidence to suggest that the mutant proteins were functional (201). More recently, inhibition of deleterious Neph-1 signaling was demonstrated with a protein transduction approach involving the introduction of the Neph-1 cytoplasmic tail, which attenuated the mislocalization of Neph-1 in two models of podocyte injury (202).

Overall, these are a selection of many encouraging observations, which indicate that adhesion-based therapy may be a prospect for glomerular disease, although there is likely to be a long journey for some of these therapies to achieve ultimate patient benefit.

\section{SUMMARY}

Podocyte adhesion is evidently important for glomerular barrier integrity. Similarly, glomerular endothelial adhesion will be the key but has not yet been investigated in detail. The genetic investigations of human nephrotic syndrome have already demonstrated the range of molecular function associated with podocytopathies and severe glomerular barrier dysfunction (Figure 7) and these

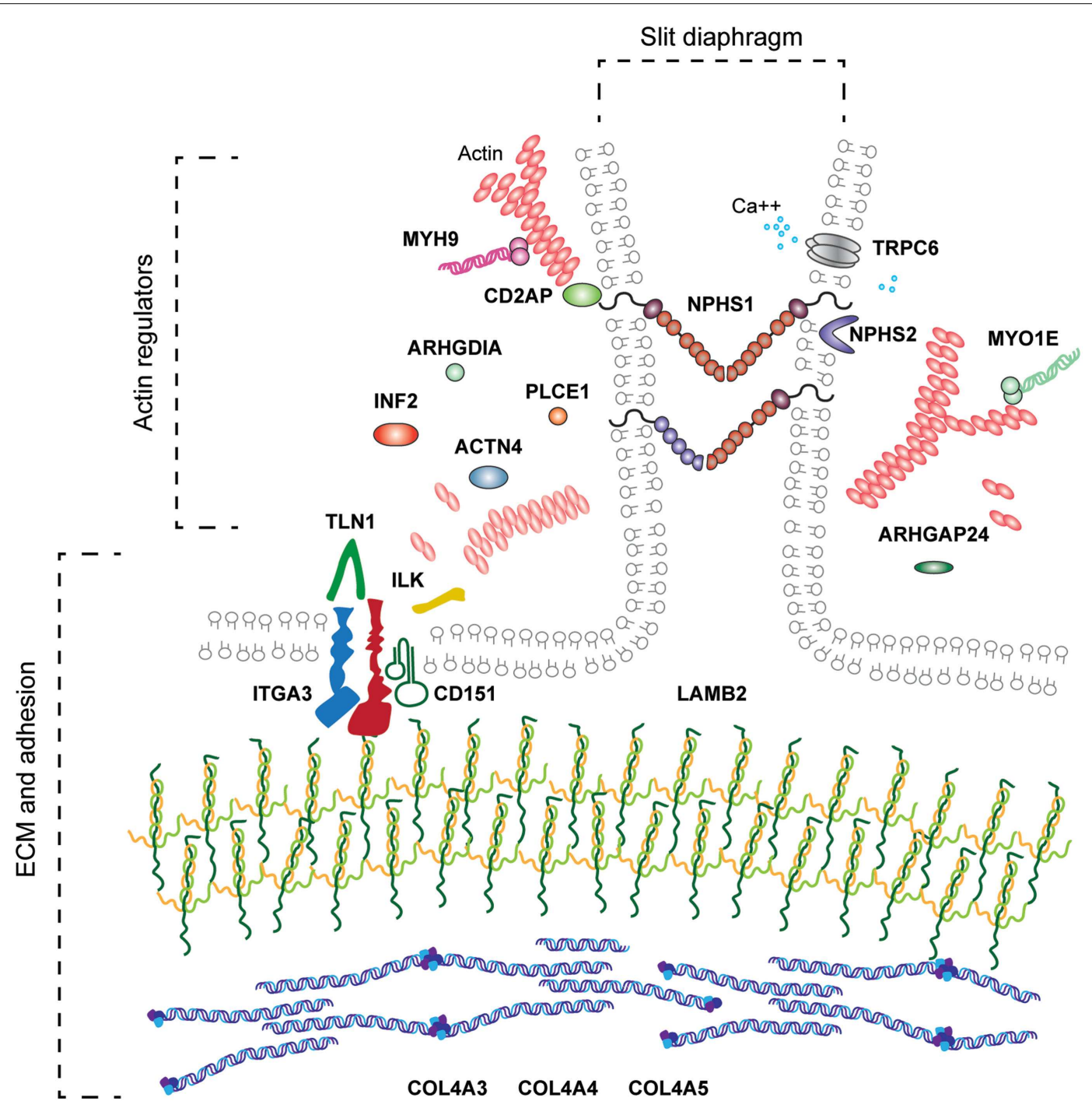

FIGURE 7 |The range of molecular functions associated with human podocytopathy. Genetic investigations in families with nephrotic syndrome have led to the discovery of molecules required for the development and or maintenance of the glomerular filter. These include molecules associated with basement membranes, ECM adhesion, cytoskeleton, slit diaphragm, mitochondrial function, and transcription factors. This review has focused on the molecules indicated in bold. 
include defects in adhesion. Networks of signaling proteins at the cell-matrix interface and the cell-cell junctions are required to maintain barrier function, and cross talk between these adhesion complexes is likely to occur in response to mechanical and chemical signals from within the glomerular microenvironment. Improved understanding about cell adhesion in the glomerulus may lead to the identification of therapies to prevent or repair injury to this highly sophisticated filter.

\section{KEY POINTS 1: MATRIX}

- Extracellular matrix controls cell fate decisions and growth factor signaling.

- The GBM is the ECM compartment of the glomerular filtration barrier.

- The GBM contains at least 73 components including laminin 521 and collagen IV $\alpha 3 \alpha 4 \alpha 5$.

- Laminins are essential for basement membrane assembly.

- Collagen IV is required for structural strength of basement membranes.

- The GBM contains two laminin networks separated by a collagen IV $\alpha 3 \alpha 4 \alpha 5$ network along the centre of the GBM.

- Mutations in LAMB2 cause Pierson syndrome in humans, and affected individuals have severe congenital nephrotic syndrome.

- Mutations leading to a reduction of the collagen IV $\alpha 3 \alpha 4 \alpha 5$ networks cause Alport syndrome humans, affected individuals have progressive renal disease.

\section{KEY POINTS 2: CELL-MATRIX ADHESION}

- Integrins link the extracellular environment to the actin cytoskeleton.

- Integrins do not have intrinsic enzymatic activity; therefore, they recruit effector proteins, which mediate adhesion signaling.

- The laminin receptor integrin $\alpha 3 \beta 1$ is the most highly expressed integrin on the podocyte cell surface.

- Homozygous mutations in ITGA3 in humans lead to congenital nephrotic syndrome.

- The tetraspanin CD151 binds tightly to integrin $\alpha 3 \beta 1$ and individuals with mutations in CD151 develop nephritis.

- Other podocyte cell surface receptors include syndecans and dystroglycan, but the importance of these receptors in the podocyte has yet to be fully determined.

\section{KEY POINTS 3: ADHESION COMPLEXES}

- Adhesion complexes contain over 232 components, which are dependent on cell type and context.

- Talin is an important linkage from integrins to the actin cytoskeleton; podocyte-specific talin 1 knockout mice develop proteinuria and die within 10 weeks.

- Focal adhesion kinase (FAK) is activated in podocytes during glomerular injury.

- Use of FAK inhibitors in mouse models of glomerular disease protects podocyte from injury and the animals from proteinuria.

- The ILK, PINCH, parvin axis is another key linkage from integrins to the actin cytoskeleton.

- Mice, which express ILK, that cannot bind to $\alpha$-parvin display renal agenesis.
- Mice with podocyte-specific deletion of ILK express GBM defects, loss of slit diaphragms, and podocyte foot process effacement.

\section{KEY POINTS 4: CELL-CELL ADHESION}

- The junction between adjacent podocyte foot processes, termed the slit diaphragm, contains both adherens and tight junction components, in addition to unique components.

- Nephrin and the other NEPH family proteins are key members of this cell junction.

- Mutations in slit diaphrgam proteins cause nephrotic syndrome.

- Slit diaphragm signalling has a major influence on the actin cytoskeleton; adaptors such as NCK1/2, CD2AP, and CRK1/2 are involved in slit diaphragm actin linkage.

\section{AUTHOR CONTRIBUTIONS}

Rachel Lennon and Michael J. Randles researched the literature for this review; Michael J. Randles prepared the figures; and Rachel Lennon, Michael J. Randles, and Martin J. Humphries contributed to the preparation of the manuscript.

\section{ACKNOWLEDGMENTS}

This work was supported by a Wellcome Trust Intermediate Fellowship award (090006) to Rachel Lennon, a Wellcome Trust grant (092015) to Martin J. Humphries, a Kids Kidney Research grant awarded to Rachel Lennon to support a PhD studentship for Michael J. Randles. We acknowledge Adam Byron for the curated protein-protein interaction network used to generate Figures 4 and 6.

\section{REFERENCES}

1. Samuel T, Hoy WE, Douglas-Denton R, Hughson MD, Bertram JF. Applicability of the glomerular size distribution coefficient in assessing human glomerular volume: the Weibel and Gomez method revisited. J Anat (2007) 210:578-82. doi:10.1111/j.1469-7580.2007.00715.x

2. Singh A, Satchell SC, Neal CR, McKenzie EA, Tooke JE, Mathieson PW. Glomerular endothelial glycocalyx constitutes a barrier to protein permeability. J Am Soc Nephrol (2007) 18:2885-93. doi:10.1681/ASN.2007010119

3. Keller G, Zimmer G, Mall G, Ritz E, Amann K. Nephron number in patients with primary hypertension. N Engl J Med (2003) 348:101-8. doi:10.1056/ NEJMoa020549

4. Couser W. Recurrent glomerulonephritis in the renal allograft: an update of selected areas. Exp Clin Transplant (2005) 3:283-8.

5. Hynes RO. The extracellular matrix: not just pretty fibrils. Science (2009) 326:1216-9. doi:10.1126/science.1176009

6. Hynes RO. Integrins: bidirectional, allosteric signaling machines. Cell (2002) 110:673-87. doi:10.1016/S0092-8674(02)00971-6

7. Tryggvason K, Patrakka J, Wartiovaara J. Hereditary proteinuria syndromes and mechanisms of proteinuria. N Engl J Med (2006) 354:1387-401. doi:10. 1056/NEJMra052131

8. Miner JH, Sanes JR. Collagen IV alpha 3, alpha 4, and alpha 5 chains in rodent basal laminae: sequence, distribution, association with laminins, and developmental switches. J Cell Biol (1994) 127:879-91. doi:10.1083/jcb.127.3.879

9. Miner JH, Patton BL, Lentz SI, Gilbert DJ, Snider WD, Jenkins NA, et al. The laminin alpha chains: expression, developmental transitions, and chromosomal locations of alphal-5, identification of heterotrimeric laminins 811, and cloning of a novel alpha3 isoform. J Cell Biol (1997) 137:685-701. doi:10.1083/jcb.137.3.685

10. Yurchenco PD, Tsilibary EC, Charonis AS, Furthmayr H. Laminin polymerization in vitro. Evidence for a two-step assembly with domain specificity. J Biol Chem (1985) 260:7636-44. 
11. Paulsson M. The role of $\mathrm{Ca} 2+$ binding in the self-aggregation of lamininnidogen complexes. J Biol Chem (1988) 263:5425-30.

12. Smyth N, Vatansever HS, Murray P, Meyer M, Frie C, Paulsson M, et al. Absence of basement membranes after targeting the LAMC1 gene results in embryonic lethality due to failure of endoderm differentiation. J Cell Biol (1999) 144:151-60. doi:10.1083/jcb.144.1.151

13. Miner JH, Li C, Mudd JL, Go G, Sutherland AE. Compositional and structural requirements for laminin and basement membranes during mouse embryo implantation and gastrulation. Development (2004) 131:2247-56. doi:10.1242/dev.01112

14. Schittny JC, Yurchenco PD. Terminal short arm domains of basement membrane laminin are critical for its self-assembly. J Cell Biol (1990) 110:825-32. doi:10.1083/jcb.110.3.825

15. Yurchenco PD, Cheng YS. Self-assembly and calcium-binding sites in laminin. A three-arm interaction model. J Biol Chem (1993) 268:17286-99.

16. Purvis A, Hohenester E. Laminin network formation studied by reconstitution of ternary nodes in solution. J Biol Chem (2012) 287:44270-7. doi:10.1074/jbc.M112.418426

17. Colognato-Pyke H, O’Rear JJ, Yamada Y, Carbonetto S, Cheng YS, Yurchenco PD. Mapping of network-forming, heparin-binding, and alpha 1 beta 1 integrin-recognition sites within the alpha-chain short arm of laminin-1. J Biol Chem (1995) 270:9398-406. doi:10.1074/jbc.270.16.9398

18. Colognato H, Maccarrick M, O'Rear JJ, Yurchenco PD. The laminin alpha2chain short arm mediates cell adhesion through both the alphalbetal and alpha2beta1 integrins. J Biol Chem (1997) 272:29330-6. doi:10.1074/jbc.272. 46.29330

19. Nielsen PK, Yamada Y. Identification of cell-binding sites on the laminin alpha $5 \mathrm{~N}$-terminal domain by site-directed mutagenesis. J Biol Chem (2001) 276:10906-12. doi:10.1074/jbc.M008743200

20. Garbe JH, Gohring W, Mann K, Timpl R, Sasaki T. Complete sequence, recombinant analysis and binding to laminins and sulphated ligands of the $\mathrm{N}$ terminal domains of laminin alpha3B and alpha5 chains. Biochem J (2002) 362:213-21. doi:10.1042/0264-6021:3620213

21. Nishiuchi R, Takagi J, Hayashi M, Ido H, Yagi Y, Sanzen N, et al. Ligandbinding specificities of laminin-binding integrins: a comprehensive survey of laminin-integrin interactions using recombinant alpha3beta1, alpha6beta1, alpha7betal and alpha6beta4 integrins. Matrix Biol (2006) 25:189-97. doi:10. 1016/j.matbio.2005.12.001

22. Pierson M, Cordier J, Hervouuet F, Rauber G. An unusual congenital and familial congenital malformative combination involving the eye and kidney. J Genet Hum (1963) 12:184-213.

23. Matejas V, Hinkes B, Alkandari F, Al-Gazali L, Annexstad E, Aytac MB, et al. Mutations in the human laminin beta2 (LAMB2) gene and the associated phenotypic spectrum. Hum Mutat (2010) 31:992-1002. doi:10.1002/humu.21304

24. Noakes PG, Miner JH, Gautam M, Cunningham JM, Sanes JR, Merlie JP. The renal glomerulus of mice lacking s-laminin/laminin beta 2: nephrosis despite molecular compensation by laminin beta 1. Nat Genet (1995) 10:400-6. doi:10.1038/ng0895-400

25. Jarad G, Cunningham J, Shaw AS, Miner JH. Proteinuria precedes podocyte abnormalities inLamb2-/- mice, implicating the glomerular basement membrane as an albumin barrier. J Clin Invest (2006) 116:2272-9. doi:10.1172/ JCI28414

26. Suh JH, Jarad G, Vandevoorde RG, Miner JH. Forced expression of laminin betal in podocytes prevents nephrotic syndrome in mice lacking laminin beta2, a model for Pierson syndrome. Proc Natl Acad Sci U S A (2011) 108:15348-53. doi:10.1073/pnas.1108269108

27. Poschl E, Schlotzer-Schrehardt U, Brachvogel B, Saito K, Ninomiya Y, Mayer U. Collagen IV is essential for basement membrane stability but dispensable for initiation of its assembly during early development. Development (2004) 131:1619-28. doi:10.1242/dev.01037

28. Hudson BG, Tryggvason K, Sundaramoorthy M, Neilson EG. Alport's syndrome, Goodpasture's syndrome, and type IV collagen. N Engl J Med (2003) 348:2543-56. doi:10.1056/NEJMra022296

29. Vanacore R, Ham AJ, Voehler M, Sanders CR, Conrads TP, Veenstra TD, et al. A sulfilimine bond identified in collagen IV. Science (2009) 325:1230-4. doi:10.1126/science.1176811

30. Bhave G, Cummings CF, Vanacore RM, Kumagai-Cresse C, Ero-Tolliver IA, Rafi $\mathrm{M}$, et al. Peroxidasin forms sulfilimine chemical bonds using hypohalous acids in tissue genesis. Nat Chem Biol (2012) 8:784-90. doi:10.1038/nchembio.1038
31. McCall AS, Cummings CF, Bhave G, Vanacore R, Page-McCaw A, Hudson BG. Bromine is an essential trace element for assembly of collagen IV scaffolds in tissue development and architecture. Cell (2014) 157:1380-92. doi:10.1016/j.cell.2014.05.009

32. Hudson BG. The molecular basis of Goodpasture and Alport syndromes: beacons for the discovery of the collagen IV family. J Am Soc Nephrol (2004) 15:2514-27. doi:10.1097/01.ASN.0000141462.00630.76

33. Grodecki KM, Gains MJ, Baumal R, Osmond DH, Cotter B, Valli VE, et al. Treatment of X-linked hereditary nephritis in samoyed dogs with angiotensin converting enzyme (ACE) inhibitor. J Comp Pathol (1997) 117:209-25. doi:10. 1016/S0021-9975(97)80016-3

34. Gross O, Beirowski B, Koepke ML, Kuck J, Reiner M, Addicks K, et al. Preemptive ramipril therapy delays renal failure and reduces renal fibrosis in COL4A3-knockout mice with Alport syndrome. Kidney Int (2003) 63:438-46. doi:10.1046/j.1523-1755.2003.00779.x

35. Gross O, Licht C, Anders HJ, Hoppe B, Beck B, Tonshoff B, et al. Early angiotensin-converting enzyme inhibition in Alport syndrome delays renal failure and improves life expectancy. Kidney Int (2012) 81:494-501. doi:10. 1038/ki.2011.407

36. Fox JW, Mayer U, Nischt R, Aumailley M, Reinhardt D, Wiedemann H, et al. Recombinant nidogen consists of three globular domains and mediates binding of laminin to collagen type IV. EMBO J (1991) 10:3137-46.

37. Arikawa-Hirasawa E, Watanabe H, Takami H, Hassell JR, Yamada Y. Perlecan is essential for cartilage and cephalic development. Nat Genet (1999) 23:354-8. doi:10.1038/15537

38. Costell M, Gustafsson E, Aszodi A, Morgelin M, Bloch W, Hunziker E, et al. Perlecan maintains the integrity of cartilage and some basement membranes. J Cell Biol (1999) 147:1109-22. doi:10.1083/jcb.147.5.1109

39. Gautam M, Noakes PG, Moscoso L, Rupp F, Scheller RH, Merlie JP, et al. Defective neuromuscular synaptogenesis in agrin-deficient mutant mice. Cell (1996) 85:525-35. doi:10.1016/S0092-8674(00)81253-2

40. Goldberg S, Harvey SJ, Cunningham J, Tryggvason K, Miner JH. Glomerular filtration is normal in the absence of both agrin and perlecan-heparan sulfate from the glomerular basement membrane. Nephrol Dial Transplant (2009) 24:2044-51. doi:10.1093/ndt/gfn758

41. Bader BL, Smyth N, Nedbal S, Miosge N, Baranowsky A, Mokkapati S, et al. Compound genetic ablation of nidogen 1 and 2 causes basement membrane defects and perinatal lethality in mice. Mol Cell Biol (2005) 25:6846-56. doi:10.1128/MCB.25.15.6846-6856.2005

42. Suleiman H, Zhang L, Roth R, Heuser JE, Miner JH, Shaw AS, et al. Nanoscale protein architecture of the kidney glomerular basement membrane. Elife (2013) 2:e01149. doi:10.7554/eLife.01149

43. Lennon R, Byron A, Humphries JD, Randles MJ, Carisey A, Murphy S, et al. Global analysis reveals the complexity of the human glomerular extracellular matrix. J Am Soc Nephrol (2014) 25(5):939-51. doi:10.1681/ASN. 2013030233

44. Byron A, Randles MJ, Humphries JD, Mironov A, Hamidi H, Harris S, et al. Glomerular cell cross-talk influences composition and assembly of extracellular matrix. J Am Soc Nephrol (2014) 25(5):953-66. doi:10.1681/ASN.2013070795

45. Sachs N, Sonnenberg A. Cell-matrix adhesion of podocytes in physiology and disease. Nat Rev Nephrol (2013) 9:200-10. doi:10.1038/nrneph.2012.291

46. Askari JA, Buckley PA, Mould AP, Humphries MJ. Linking integrin conformation to function. J Cell Sci (2009) 122:165-70. doi:10.1242/jcs.018556

47. Byron A, Humphries JD, Craig SE, Knight D, Humphries MJ. Proteomic analysis of alpha4betal integrin adhesion complexes reveals alpha-subunitdependent protein recruitment. Proteomics (2012) 12:2107-14. doi:10.1002/ pmic.201100487

48. Humphries JD, Byron A, Humphries MJ. Integrin ligands at a glance. J Cell Sci (2006) 119:3901-3. doi:10.1242/jcs.03098

49. Winograd-Katz SE, Fassler R, Geiger B, Legate KR. The integrin adhesome: from genes and proteins to human disease. Nat Rev Mol Cell Biol (2014) 15:273-88. doi:10.1038/nrm3769

50. Humphries JD, Byron A, Bass MD, Craig SE, Pinney JW, Knight D, et al. Proteomic analysis of integrin-associated complexes identifies RCC2 as a dual regulator of Racl and Arf6. Sci Signal (2009) 2:ra51. doi:10.1126/scisignal.2000396

51. Kuo JC, Han X, Hsiao CT, Yates JR III, Waterman CM. Analysis of the myosinII-responsive focal adhesion proteome reveals a role for beta-Pix in negative regulation of focal adhesion maturation. Nat Cell Biol (2011) 13:383-93. doi: $10.1038 /$ ncb2216 
52. Schiller HB, Hermann MR, Polleux J, Vignaud T, Zanivan S, Friedel CC, et al. Beta1- and alphav-class integrins cooperate to regulate myosin II during rigidity sensing of fibronectin-based microenvironments. Nat Cell Biol (2013) 15:625-36. doi:10.1038/ncb2747

53. Woods A, Couchman JR. Integrin modulation by lateral association. J Biol Chem (2000) 275:24233-6. doi:10.1074/jbc.R000001200

54. Morgan MR, Humphries MJ, Bass MD. Synergistic control of cell adhesion by integrins and syndecans. Nat Rev Mol Cell Biol (2007) 8:957-69. doi: $10.1038 / \mathrm{nrm} 2289$

55. Korhonen M, Ylanne J, Laitinen L, Virtanen I. The alpha 1-alpha 6 subunits of integrins are characteristically expressed in distinct segments of developing and adult human nephron. J Cell Biol (1990) 111:1245-54. doi:10.1083/jcb. 111.3.1245

56. Baraldi A, Furci L, Zambruno G, Rubbiani E, Annessi G, Lusvarghi E. Very late activation-3 integrin is the dominant beta 1-integrin on the glomerular capillary wall: an immunofluorescence study in nephrotic syndrome. Nephron (1992) 62:382-8. doi:10.1159/000187085

57. Sterk LM, De Melker AA, Kramer D, Kuikman I, Chand A, Claessen N, et al. Glomerular extracellular matrix components and integrins. Cell Adhes Commun (1998) 5:177-92. doi:10.3109/15419069809040290

58. Has C, Sparta G, Kiritsi D, Weibel L, Moeller A, Vega-Warner V, et al. Integrin alpha3 mutations with kidney, lung, and skin disease. N Engl J Med (2012) 366:1508-14. doi:10.1056/NEJMoa1110813

59. Nicolaou N, Margadant C, Kevelam SH, Lilien MR, Oosterveld MJ, Kreft M, et al. Gain of glycosylation in integrin alpha3 causes lung disease and nephrotic syndrome. J Clin Invest (2012) 122:4375-87. doi:10.1172/JCI64100

60. Kreidberg JA, Donovan MJ, Goldstein SL, Rennke H, Shepherd K, Jones RC, et al. Alpha 3 beta 1 integrin has a crucial role in kidney and lung organogenesis. Development (1996) 122:3537-47.

61. Sachs N, Kreft M, Van Den Bergh Weerman MA, Beynon AJ, Peters TA, Weening JJ, et al. Kidney failure in mice lacking the tetraspanin CD151. J Cell Biol (2006) 175:33-9. doi:10.1083/jcb.200603073

62. Kanasaki K, Kanda Y, Palmsten K, Tanjore H, Lee SB, Lebleu VS, et al. Integrin betal-mediated matrix assembly and signaling are critical for the normal development and function of the kidney glomerulus. Dev Biol (2008) 313:584-93. doi:10.1016/j.ydbio.2007.10.047

63. Pozzi A, Jarad G, Moeckel GW, Coffa S, Zhang X, Gewin L, et al. Betal integrin expression by podocytes is required to maintain glomerular structural integrity. Dev Biol (2008) 316:288-301. doi:10.1016/j.ydbio.2008.01.022

64. Yauch RL, Berditchevski F, Harler MB, Reichner J, Hemler ME. Highly stoichiometric, stable, and specific association of integrin alpha3betal with CD151 provides a major link to phosphatidylinositol 4-kinase, and may regulate cell migration. Mol Biol Cell (1998) 9:2751-65. doi:10.1091/mbc.9.10.2751

65. Karamatic Crew V, Burton N, Kagan A, Green CA, Levene C, Flinter F, et al. CD151, the first member of the tetraspanin (TM4) superfamily detected on erythrocytes, is essential for the correct assembly of human basement membranes in kidney and skin. Blood (2004) 104:2217-23. doi:10.1182/blood2004-04- 1512

66. Baleato RM, Guthrie PL, Gubler MC, Ashman LK, Roselli S. Deletion of CD151 results in a strain-dependent glomerular disease due to severe alterations of the glomerular basement membrane. Am J Pathol (2008) 173:927-37. doi:10.2353/ajpath.2008.071149

67. Sachs N, Claessen N, Aten J, Kreft M, Teske GJ, Koeman A, et al. Blood pressure influences end-stage renal disease of Cd151 knockout mice. J Clin Invest (2012) 122:348-58. doi:10.1172/JCI58878

68. Vidal F, Aberdam D, Miquel C, Christiano AM, Pulkkinen L, Uitto J, et al. Integrin beta 4 mutations associated with junctional epidermolysis bullosa with pyloric atresia. Nat Genet (1995) 10:229-34. doi:10.1038/ng0695-229

69. Kambham N, Tanji N, Seigle RL, Markowitz GS, Pulkkinen L, Uitto J, et al. Congenital focal segmental glomerulosclerosis associated with beta4 integrin mutation and epidermolysis bullosa. Am J Kidney Dis (2000) 36:190-6. doi:10.1053/ajkd.2000.8293

70. Wei C, Moller CC, Altintas MM, Li J, Schwarz K, Zacchigna S, et al. Modification of kidney barrier function by the urokinase receptor. Nat Med (2008) 14:55-63. doi:10.1038/nm1696

71. Amann K, Haas CS, Schussler J, Daniel C, Hartner A, Schocklmann HO. Beneficial effects of integrin alphavbeta3-blocking RGD peptides in early but not late phase of experimental glomerulonephritis. Nephrol Dial Transplant (2012) 27:1755-68. doi:10.1093/ndt/gfr603
72. Wei C, El Hindi S, Li J, Fornoni A, Goes N, Sageshima J, et al. Circulating urokinase receptor as a cause of focal segmental glomerulosclerosis. Nat Med (2011) 17:952-60. doi:10.1038/nm.2411

73. Beauvais DM, Burbach BJ, Rapraeger AC. The syndecan-1 ectodomain regulates alphavbeta3 integrin activity in human mammary carcinoma cells. J Cell Biol (2004) 167:171-81. doi:10.1083/jcb.200404171

74. Hozumi K, Suzuki N, Nielsen PK, Nomizu M, Yamada Y. Laminin alpha1 chain LG4 module promotes cell attachment through syndecans and cell spreading through integrin alpha2betal. J Biol Chem (2006) 281:32929-40. doi:10.1074/jbc.M605708200

75. McQuade KJ, Beauvais DM, Burbach BJ, Rapraeger AC. Syndecan-1 regulates alphavbeta5 integrin activity in B82L fibroblasts. J Cell Sci (2006) 119:2445-56. doi:10.1242/jcs.02970

76. Ogawa T, Tsubota Y, Hashimoto J, Kariya Y, Miyazaki K. The short arm of laminin gamma2 chain of laminin-5 (laminin-332) binds syndecan-1 and regulates cellular adhesion and migration by suppressing phosphorylation of integrin beta4 chain. Mol Biol Cell (2007) 18:1621-33. doi:10.1091/mbc.E0609-0806

77. Morgan MR, Hamidi H, Bass MD, Warwood S, Ballestrem C, Humphries MJ. Syndecan-4 phosphorylation is a control point for integrin recycling. Dev Cell (2013) 24:472-85. doi:10.1016/j.devcel.2013.01.027

78. Caswell PT, Vadrevu S, Norman JC. Integrins: masters and slaves of endocytic transport. Nat Rev Mol Cell Biol (2009) 10:843-53. doi:10.1038/nrm2799

79. Ezratty EJ, Bertaux C, Marcantonio EE, Gundersen GG. Clathrin mediates integrin endocytosis for focal adhesion disassembly in migrating cells. J Cell Biol (2009) 187:733-47. doi:10.1083/jcb.200904054

80. Huttenlocher A, Horwitz AR. Integrins in cell migration. Cold Spring Harb Perspect Biol (2011) 3:a005074. doi:10.1101/cshperspect.a005074

81. Fears CY, Woods A. The role of syndecans in disease and wound healing. Matrix Biol (2006) 25:443-56. doi:10.1016/j.matbio.2006.07.003

82. Jakobsson L, Kreuger J, Holmborn K, Lundin L, Eriksson I, Kjellen L, et al. Heparan sulfate in trans potentiates VEGFR-mediated angiogenesis. Dev Cell (2006) 10:625-34. doi:10.1016/j.devcel.2006.03.009

83. Chen S, Wassenhove-McCarthy D, Yamaguchi Y, Holzman L, Van Kuppevelt $\mathrm{TH}$, Orr AW, et al. Podocytes require the engagement of cell surface heparan sulfate proteoglycans for adhesion to extracellular matrices. Kidney Int (2010) 78:1088-99. doi:10.1038/ki.2010.136

84. Chen S, Wassenhove-McCarthy DJ, Yamaguchi Y, Holzman LB, Van Kuppevelt TH, Jenniskens GJ, et al. Loss of heparan sulfate glycosaminoglycan assembly in podocytes does not lead to proteinuria. Kidney Int (2008) 74:289-99. doi:10.1038/ki.2008.159

85. Jin J, Sison K, Li C, Tian R, Wnuk M, Sung HK, et al. Soluble FLT1 binds lipid microdomains in podocytes to control cell morphology and glomerular barrier function. Cell (2012) 151:384-99. doi:10.1016/j.cell.2012.08.037

86. Ervasti JM, Campbell KP. A role for the dystrophin-glycoprotein complex as a transmembrane linker between laminin and actin. J Cell Biol (1993) 122:809-23. doi:10.1083/jcb.122.4.809

87. Gee SH, Blacher RW, Douville PJ, Provost PR, Yurchenco PD, Carbonetto S. Laminin-binding protein 120 from brain is closely related to the dystrophinassociated glycoprotein, dystroglycan, and binds with high affinity to the major heparin binding domain of laminin. J Biol Chem (1993) 268:14972-80.

88. Durbeej M, Henry MD, Ferletta M, Campbell KP, Ekblom P. Distribution of dystroglycan in normal adult mouse tissues. J Histochem Cytochem (1998) 46:449-57. doi:10.1177/002215549804600404

89. Raats CJ, Van Den Born J, Bakker MA, Oppers-Walgreen B, Pisa BJ, Dijkman $\mathrm{HB}$, et al. Expression of agrin, dystroglycan, and utrophin in normal renal tissue and in experimental glomerulopathies. Am J Pathol (2000) 156:1749-65. doi:10.1016/S0002-9440(10)65046-8

90. Kojima K, Davidovits A, Poczewski H, Langer B, Uchida S, Nagy-Bojarski K, et al. Podocyte flattening and disorder of glomerular basement membrane are associated with splitting of dystroglycan-matrix interaction. J Am Soc Nephrol (2004) 15:2079-89. doi:10.1097/01.ASN.0000133531.43177.21

91. Kojima K, Nosaka H, Kishimoto Y, Nishiyama Y, Fukuda S, Shimada M, et al. Defective glycosylation of alpha-dystroglycan contributes to podocyte flattening. Kidney Int (2011) 79:311-6. doi:10.1038/ki.2010.403

92. Jarad G, Pippin JW, Shankland SJ, Kreidberg JA, Miner JH. Dystroglycan does not contribute significantly to kidney development or function, in health or after injury. Am J Physiol Renal Physiol (2011) 300:F811-20. doi:10.1152/ajprenal.00725.2010 
93. Goult BT, Zacharchenko T, Bate N, Tsang R, Hey F, Gingras AR, et al. RIAM and vinculin binding to talin are mutually exclusive and regulate adhesion assembly and turnover. J Biol Chem (2013) 288:8238-49. doi:10.1074/jbc.M112.438119

94. Critchley DR, Gingras AR. Talin at a glance. J Cell Sci (2008) 121:1345-7. doi:10.1242/jcs.018085

95. Tian X, Kim JJ, Monkley SM, Gotoh N, Nandez R, Soda K, et al. Podocyteassociated talin 1 is critical for glomerular filtration barrier maintenance. J Clin Invest (2014) 124:1098-113. doi:10.1172/JCI69778

96. Humphries JD, Wang P, Streuli C, Geiger B, Humphries MJ, Ballestrem C. Vinculin controls focal adhesion formation by direct interactions with talin and actin. J Cell Biol (2007) 179:1043-57. doi:10.1083/jcb.200703036

97. Eimer W, Niermann M, Eppe MA, Jockusch BM. Molecular shape of vinculin in aqueous solution. J Mol Biol (1993) 229:146-52. doi:10.1006/jmbi.1993.1014

98. Winkler J, Lunsdorf H, Jockusch BM. The ultrastructure of chicken gizzard vinculin as visualized by high-resolution electron microscopy. J Struct Biol (1996) 116:270-7. doi:10.1006/jsbi.1996.0042

99. Chen H, Cohen DM, Choudhury DM, Kioka N, Craig SW. Spatial distribution and functional significance of activated vinculin in living cells. J Cell Biol (2005) 169:459-70. doi:10.1083/jcb.200410100

100. Bakolitsa C, Cohen DM, Bankston LA, Bobkov AA, Cadwell GW, Jennings L, et al. Structural basis for vinculin activation at sites of cell adhesion. Nature (2004) 430:583-6. doi:10.1038/nature02610

101. Carisey A, Tsang R, Greiner AM, Nijenhuis N, Heath N, Nazgiewicz A, et al. Vinculin regulates the recruitment and release of core focal adhesion proteins in a force-dependent manner. Curr Biol (2013) 23:271-81. doi:10.1016/j.cub.2013.01.009

102. Zamir E, Geiger B. Molecular complexity and dynamics of cell-matrix adhesions. J Cell Sci (2001) 114:3583-90.

103. Ziegler WH, Liddington RC, Critchley DR. The structure and regulation of vinculin. Trends Cell Biol (2006) 16:453-60. doi:10.1016/j.tcb.2006.07.004

104. Brown MC, Perrotta JA, Turner CE. Identification of LIM3 as the principal determinant of paxillin focal adhesion localization and characterization of a novel motif on paxillin directing vinculin and focal adhesion kinase binding. J Cell Biol (1996) 135:1109-23. doi:10.1083/jcb.135.4.1109

105. Brown MC, Perrotta JA, Turner CE. Serine and threonine phosphorylation of the paxillin LIM domains regulates paxillin focal adhesion localization and cell adhesion to fibronectin. Mol Biol Cell (1998) 9:1803-16. doi: $10.1091 / \mathrm{mbc}$.9.7.1803

106. Wang P, Ballestrem C, Streuli CH. The C terminus of talin links integrins to cell cycle progression. J Cell Biol (2011) 195:499-513. doi:10.1083/jcb.201104128

107. Brown MC, Turner CE. Paxillin: adapting to change. Physiol Rev (2004) 84:1315-39. doi:10.1152/physrev.00002.2004

108. Schaller MD, Borgman CA, Cobb BS, Vines RR, Reynolds AB, Parsons JT. pp125FAK a structurally distinctive protein-tyrosine kinase associated with focal adhesions. Proc Natl Acad Sci U S A (1992) 89:5192-6. doi:10.1073/pnas. 89.11 .5192

109. Schaller MD. Cellular functions of FAK kinases: insight into molecular mechanisms and novel functions. J Cell Sci (2010) 123:1007-13. doi:10.1242/jcs. 045112

110. Ilic D, Furuta Y, Kanazawa S, Takeda N, Sobue K, Nakatsuji N, et al. Reduced cell motility and enhanced focal adhesion contact formation in cells from FAKdeficient mice. Nature (1995) 377:539-44. doi:10.1038/377539a0

111. Ma H, Togawa A, Soda K, Zhang J, Lee S, Ma M, et al. Inhibition of podocyte FAK protects against proteinuria and foot process effacement. J Am Soc Nephrol (2010) 21:1145-56. doi:10.1681/ASN.2009090991

112. Delimont D, Dufek BM, Meehan DT, Zallocchi M, Gratton MA, Phillips G, et al. Laminin alpha2-mediated focal adhesion kinase activation triggers Alport glomerular pathogenesis. PLoS One (2014) 9:e99083. doi:10.1371/journal. pone.0099083

113. Hannigan GE, Leung-Hagesteijn C, Fitz-Gibbon L, Coppolino MG, Radeva G, Filmus J, et al. Regulation of cell adhesion and anchorage-dependent growth by a new beta 1-integrin-linked protein kinase. Nature (1996) 379:91-6. doi:10.1038/379091a0

114. Zervas CG, Gregory SL, Brown NH. Drosophila integrin-linked kinase is required at sites of integrin adhesion to link the cytoskeleton to the plasma membrane. J Cell Biol (2001) 152:1007-18. doi:10.1083/jcb.152.5.1007

115. Mackinnon AC, Qadota H, Norman KR, Moerman DG, Williams BD. C. elegans PAT-4/ILK functions as an adaptor protein within integrin adhesion complexes. Curr Biol (2002) 12:787-97. doi:10.1016/S0960-9822(02)00810-2
116. Wickstrom SA, Lange A, Montanez E, Fassler R. The ILK/PINCH/parvin complex: the kinase is dead, long live the pseudokinase! EMBO J (2010) 29:281-91. doi:10.1038/emboj.2009.376

117. Fukuda K, Knight JD, Piszczek G, Kothary R, Qin J. Biochemical, proteomic, structural, and thermodynamic characterizations of integrin-linked kinase (ILK): cross-validation of the pseudokinase. J Biol Chem (2011) 286:21886-95. doi:10.1074/jbc.M111.240093

118. Hannigan GE, McDonald PC, Walsh MP, Dedhar S. Integrin-linked kinase: not so "pseudo" after all. Oncogene (2011) 30:4375-85. doi:10.1038/onc.2011.177

119. Qin J, Wu C. ILK: a pseudokinase in the center stage of cell-matrix adhesion and signaling. Curr Opin Cell Biol (2012) 24:607-13. doi:10.1016/j.ceb.2012.06.003

120. Nikolopoulos SN, Turner CE. Actopaxin, a new focal adhesion protein that binds paxillin LD motifs and actin and regulates cell adhesion. J Cell Biol (2000) 151:1435-48. doi:10.1083/jcb.151.7.1435

121. Yamaji S, Suzuki A, Sugiyama Y, Koide Y, Yoshida M, Kanamori H, et al. A novel integrin-linked kinase-binding protein, affixin, is involved in the early stage of cell-substrate interaction. J Cell Biol (2001) 153:1251-64. doi:10.1083/jcb.153.6.1251

122. Tu Y, Li F, Goicoechea S, Wu C. The LIM-only protein PINCH directly interacts with integrin-linked kinase and is recruited to integrin-rich sites in spreading cells. Mol Cell Biol (1999) 19:2425-34.

123. Tu Y, Huang Y, Zhang Y, Hua Y, Wu C. A new focal adhesion protein that interacts with integrin-linked kinase and regulates cell adhesion and spreading. J Cell Biol (2001) 153:585-98. doi:10.1083/jcb.153.3.585

124. Chiswell BP, Zhang R, Murphy JW, Boggon TJ, Calderwood DA. The structural basis of integrin-linked kinase-PINCH interactions. Proc Natl Acad Sci U S A (2008) 105:20677-82. doi:10.1073/pnas.0811415106

125. Tu Y, Wu S, Shi X, Chen K, Wu C. Migfilin and Mig-2 link focal adhesions to filamin and the actin cytoskeleton and function in cell shape modulation. Cell (2003) 113:37-47. doi:10.1016/S0092-8674(03)00163-6

126. Larjava H, Plow EF, Wu C. Kindlins: essential regulators of integrin signalling and cell-matrix adhesion. EMBO Rep (2008) 9:1203-8. doi:10.1038/embor. 2008.202

127. Qu H, Tu Y, Shi X, Larjava H, Saleem MA, Shattil SJ, et al. Kindlin-2 regulates podocyte adhesion and fibronectin matrix deposition through interactions with phosphoinositides and integrins. J Cell Sci (2011) 124:879-91. doi:10.1242/jcs.076976

128. Sakai T, Li S, Docheva D, Grashoff C, Sakai K, Kostka G, et al. Integrin-linked kinase (ILK) is required for polarizing the epiblast, cell adhesion, and controlling actin accumulation. Genes Dev (2003) 17:926-40. doi:10.1101/gad.255603

129. Montanez E, Wickstrom SA, Altstatter J, Chu H, Fassler R. Alpha-parvin controls vascular mural cell recruitment to vessel wall by regulating RhoA/ROCK signalling. EMBO J (2009) 28:3132-44. doi:10.1038/emboj.2009.295

130. Li S, Bordoy R, Stanchi F, Moser M, Braun A, Kudlacek O, et al. PINCH1 regulates cell-matrix and cell-cell adhesions, cell polarity and cell survival during the peri-implantation stage. J Cell Sci (2005) 118:2913-21. doi:10.1242/jcs.02422

131. Lange A, Wickstrom SA, Jakobson M, Zent R, Sainio K, Fassler R. Integrinlinked kinase is an adaptor with essential functions during mouse development. Nature (2009) 461:1002-6. doi:10.1038/nature08468

132. Dai C, Stolz DB, Bastacky SI, St-Arnaud R, Wu C, Dedhar S, et al. Essential role of integrin-linked kinase in podocyte biology: bridging the integrin and slit diaphragm signaling. J Am Soc Nephrol (2006) 17:2164-75. doi:10.1681/ASN.2006010033

133. El-Aouni C, Herbach N, Blattner SM, Henger A, Rastaldi MP, Jarad G, et al. Podocyte-specific deletion of integrin-linked kinase results in severe glomerular basement membrane alterations and progressive glomerulosclerosis. J Am Soc Nephrol (2006) 17:1334-44. doi:10.1681/ASN.2005090921

134. Guo L, Sanders PW, Woods A, Wu C. The distribution and regulation of integrin-linked kinase in normal and diabetic kidneys. Am J Pathol (2001) 159:1735-42. doi:10.1016/S0002-9440(10)63020-9

135. Kretzler M, Teixeira VP, Unschuld PG, Cohen CD, Wanke R, Edenhofer I, et al. Integrin-linked kinase as a candidate downstream effector in proteinuria. FASEB J (2001) 15:1843-5.

136. Rodewald R, Karnovsky MJ. Porous substructure of the glomerular slit diaphragm in the rat and mouse. J Cell Biol (1974) 60:423-33. doi:10.1083/ jcb.60.2.423

137. Farquhar MG, Wissig SL, Palade GE. Glomerular permeability. I. Ferritin transfer across the normal glomerular capillary wall. J Exp Med (1961) 113:47-66. doi:10.1084/jem.113.1.47 
138. Caulfield JP, Farquhar MG. The permeability of glomerular capillaries to graded dextrans. Identification of the basement membrane as the primary filtration barrier. J Cell Biol (1974) 63:883-903. doi:10.1083/jcb.63.3.883

139. Kestila M, Lenkkeri U, Mannikko M, Lamerdin J, McCready P, Putaala H, et al. Positionally cloned gene for a novel glomerular protein - nephrin is mutated in congenital nephrotic syndrome. Mol Cell (1998) 1:575-82. doi:10.1016/S1097-2765(00)80057-X

140. Ruotsalainen V, Ljungberg P, Wartiovaara J, Lenkkeri U, Kestila M, Jalanko $\mathrm{H}$, et al. Nephrin is specifically located at the slit diaphragm of glomerular podocytes. Proc Natl Acad Sci U S A (1999) 96:7962-7. doi:10.1073/pnas.96. 14.7962

141. Gagliardini E, Conti S, Benigni A, Remuzzi G, Remuzzi A. Imaging of the porous ultrastructure of the glomerular epithelial filtration slit. J Am Soc Nephrol (2010) 21:2081-9. doi:10.1681/ASN.2010020199

142. Caulfield JP, Reid JJ, Farquhar MG. Alterations of the glomerular epithelium in acute aminonucleoside nephrosis. Evidence for formation of occluding junctions and epithelial cell detachment. Lab Invest (1976) 34:43-59.

143. Reeves W, Caulfield JP, Farquhar MG. Differentiation of epithelial foot processes and filtration slits: sequential appearance of occluding junctions, epithelial polyanion, and slit membranes in developing glomeruli. Lab Invest (1978) 39:90-100.

144. Ciani L, Patel A, Allen ND, Ffrench-Constant C. Mice lacking the giant protocadherin mFAT1 exhibit renal slit junction abnormalities and a partially penetrant cyclopia and anophthalmia phenotype. Mol Cell Biol (2003) 23:3575-82. doi:10.1128/MCB.23.10.3575-3582.2003

145. Reiser J, Kriz W, Kretzler M, Mundel P. The glomerular slit diaphragm is a modified adherens junction. J Am Soc Nephrol (2000) 11:1-8.

146. Fukasawa H, Bornheimer S, Kudlicka K, Farquhar MG. Slit diaphragms contain tight junction proteins. J Am Soc Nephrol (2009) 20:1491-503. doi:10. 1681/ASN.2008101117

147. Yaoita E, Yao J, Yoshida Y, Morioka T, Nameta M, Takata T, et al. Up-regulation of connexin43 in glomerular podocytes in response to injury. Am J Pathol (2002) 161:1597-606. doi:10.1016/S0002-9440(10)64438-0

148. Helmstadter M, Hohne M, Huber TB. A brief overview on IRM function across evolution. J Neurogenet (2014). doi:10.3109/01677063.2014.918976

149. Weavers H, Prieto-Sanchez S, Grawe F, Garcia-Lopez A, Artero R, WilschBrauninger M, et al. The insect nephrocyte is a podocyte-like cell with a filtration slit diaphragm. Nature (2009) 457:322-6. doi:10.1038/nature07526

150. Zhuang S, Shao H, Guo F, Trimble R, Pearce E, Abmayr SM. Sns and Kirre, the Drosophila orthologs of nephrin and Neph1, direct adhesion, fusion and formation of a slit diaphragm-like structure in insect nephrocytes. Development (2009) 136:2335-44. doi:10.1242/dev.031609

151. Costa MS, Machado MC, Vieceli FM, Amista L, Baroneza JE, Yan CY, et al. The Rst-Neph family of cell adhesion molecules in Gallus gallus. J Neurogenet (2014). doi:10.3109/01677063.2014.933220

152. Ozkan E, Chia PH, Wang RR, Goriatcheva N, Borek D, Otwinowski Z, et al. Extracellular architecture of the SYG-1/SYG-2 adhesion complex instructs synaptogenesis. Cell (2014) 156:482-94. doi:10.1016/j.cell.2014.01.004

153. Khoshnoodi J, Sigmundsson K, Ofverstedt LG, Skoglund U, Obrink B, Wartiovaara J, et al. Nephrin promotes cell-cell adhesion through homophilic interactions. Am J Pathol (2003) 163:2337-46. doi:10.1016/S0002-9440(10)63590-0

154. Philippe A, Nevo F, Esquivel EL, Reklaityte D, Gribouval O, Tete MJ, et al. Nephrin mutations can cause childhood-onset steroid-resistant nephrotic syndrome. J Am Soc Nephrol (2008) 19:1871-8. doi:10.1681/ASN.2008010059

155. Putaala H, Sainio K, Sariola H, Tryggvason K. Primary structure of mouse and rat nephrin cDNA and structure and expression of the mouse gene. J Am Soc Nephrol (2000) 11:991-1001.

156. Donoviel DB, Freed DD, Vogel H, Potter DG, Hawkins E, Barrish JP, et al. Proteinuria and perinatal lethality in mice lacking NEPH1, a novel protein with homology to NEPHRIN. Mol Cell Biol (2001) 21:4829-36. doi:10.1128/MCB. 21.14.4829-4836.2001

157. Boute N, Gribouval O, Roselli S, Benessy F, Lee H, Fuchshuber A, et al. NPHS2, encoding the glomerular protein podocin, is mutated in autosomal recessive steroid-resistant nephrotic syndrome. Nat Genet (2000) 24:349-54. doi:10.1038/74166

158. Huber TB, Simons M, Hartleben B, Sernetz L, Schmidts M, Gundlach E, et al. Molecular basis of the functional podocin-nephrin complex: mutations in the NPHS2 gene disrupt nephrin targeting to lipid raft microdomains. Hum Mol Genet (2003) 12:3397-405. doi:10.1093/hmg/ddg360
159. Shih NY, Li J, Karpitskii V, Nguyen A, Dustin ML, Kanagawa O, et al. Congenital nephrotic syndrome in mice lacking CD2-associated protein. Science (1999) 286:312-5. doi:10.1126/science.286.5438.312

160. Akilesh S, Koziell A, Shaw AS. Basic science meets clinical medicine: identification of a CD2AP-deficient patient. Kidney Int (2007) 72:1181-3. doi:10.1038/ sj.ki.5002575

161. Tossidou I, Kardinal C, Peters I, Kriz W, Shaw A, Dikic I, et al. CD2AP/CIN85 balance determines receptor tyrosine kinase signaling response in podocytes. J Biol Chem (2007) 282:7457-64. doi:10.1074/jbc.M608519200

162. Lehtonen S, Ryan JJ, Kudlicka K, Iino N, Zhou H, Farquhar MG. Cell junctionassociated proteins IQGAP1, MAGI-2, CASK, spectrins, and alpha-actinin are components of the nephrin multiprotein complex. Proc Natl Acad Sci U S A (2005) 102:9814-9. doi:10.1073/pnas.0504166102

163. Zaidel-Bar R. Cadherin adhesome at a glance. J Cell Sci (2013) 126:373-8. doi:10.1242/jcs.111559

164. Grahammer F, Schell C, Huber TB. The podocyte slit diaphragm - from a thin grey line to a complex signalling hub. Nat Rev Nephrol (2013) 9:587-98. doi:10.1038/nrneph.2013.169

165. New LA, Martin CE, Jones N. Advances in slit diaphragm signaling. Curr Opin Nephrol Hypertens (2014) 23:420-30. doi:10.1097/01.mnh.0000447018. 28852.b6

166. Verma R, Wharram B, Kovari I, Kunkel R, Nihalani D, Wary KK, et al. Fyn binds to and phosphorylates the kidney slit diaphragm component nephrin. J Biol Chem (2003) 278:20716-23. doi:10.1074/jbc.M301689200

167. Jones N, Blasutig IM, Eremina V, Ruston JM, Bladt F, Li H, et al. Nck adaptor proteins link nephrin to the actin cytoskeleton of kidney podocytes. Nature (2006) 440:818-23. doi:10.1038/nature04662

168. Verma R, Kovari I, Soofi A, Nihalani D, Patrie K, Holzman LB. Nephrin ectodomain engagement results in Src kinase activation, nephrin phosphorylation, Nck recruitment, and actin polymerization. J Clin Invest (2006) 116:1346-59. doi:10.1172/JCI27414

169. George B, Verma R, Soofi AA, Garg P, Zhang J, Park TJ, et al. Crk1/2dependent signaling is necessary for podocyte foot process spreading in mouse models of glomerular disease. J Clin Invest (2012) 122:674-92. doi:10.1172/ JCI60070

170. George B, Fan Q, Dlugos CP, Soofi AA, Zhang J, Verma R, et al. Crk1/2 and CrkL form a hetero-oligomer and functionally complement each other during podocyte morphogenesis. Kidney Int (2014) 85:1382-94. doi:10.1038/ ki.2013.556

171. Garg P, Verma R, Nihalani D, Johnstone DB, Holzman LB. Neph1 cooperates with nephrin to transduce a signal that induces actin polymerization. Mol Cell Biol (2007) 27:8698-712. doi:10.1128/MCB.00948-07

172. Bisson N, Ruston J, Jeansson M, Vanderlaan R, Hardy WR, Du J, et al. The adaptor protein Grb2 is not essential for the establishment of the glomerular filtration barrier. PLoS One (2012) 7:e50996. doi:10.1371/journal.pone. 0050996

173. Huber TB, Hartleben B, Kim J, Schmidts M, Schermer B, Keil A, et al. Nephrin and CD2AP associate with phosphoinositide 3-OH kinase and stimulate AKTdependent signaling. Mol Cell Biol (2003) 23:4917-28. doi:10.1128/MCB.23. 14.4917-4928.2003

174. Zhu J, Sun N, Aoudjit L, Li H, Kawachi H, Lemay S, et al. Nephrin mediates actin reorganization via phosphoinositide 3-kinase in podocytes. Kidney Int (2008) 73:556-66. doi:10.1038/sj.ki.5002691

175. Schell C, Baumhakl L, Salou S, Conzelmann AC, Meyer C, Helmstadter M, et al. N-wasp is required for stabilization of podocyte foot processes. J Am Soc Nephrol (2013) 24:713-21. doi:10.1681/ASN.2012080844

176. Fan X, Li Q, Pisarek-Horowitz A, Rasouly HM, Wang X, Bonegio RG, et al. Inhibitory effects of Robo 2 on nephrin: a crosstalk between positive and negative signals regulating podocyte structure. Cell Rep (2012) 2:52-61. doi:10.1016/j.celrep.2012.06.002

177. Canaud G, Bienaime F, Viau A, Treins C, Baron W, Nguyen C, et al. AKT2 is essential to maintain podocyte viability and function during chronic kidney disease. Nat Med (2013) 19:1288-96. doi:10.1038/nm.3313

178. Welsh GI, Hale LJ, Eremina V, Jeansson M, Maezawa Y, Lennon R, et al. Insulin signaling to the glomerular podocyte is critical for normal kidney function. Cell Metab (2010) 12:329-40. doi:10.1016/j.cmet.2010.08.015

179. Kaplan JM, Kim SH, North KN, Rennke H, Correia LA, Tong HQ, et al. Mutations in ACTN4, encoding alpha-actinin-4, cause familial focal segmental glomerulosclerosis. Nat Genet (2000) 24:251-6. doi:10.1038/73456 
180. Scott RP, Hawley SP, Ruston J, Du J, Brakebusch C, Jones N, et al. Podocytespecific loss of Cdc42 leads to congenital nephropathy. JAm Soc Nephrol (2012) 23:1149-54. doi:10.1681/ASN.2011121206

181. Sun H, Schlondorff J, Higgs HN, Pollak MR. Inverted formin 2 regulates actin dynamics by antagonizing Rho/diaphanous-related formin signaling. J Am Soc Nephrol (2013) 24:917-29. doi:10.1681/ASN.2012080834

182. Yu H, Suleiman H, Kim AH, Miner JH, Dani A, Shaw AS, et al. Racl activation in podocytes induces rapid foot process effacement and proteinuria. Mol Cell Biol (2013) 33:4755-64. doi:10.1128/MCB.00730-13

183. Shibata S, Nagase M, Yoshida S, Kawarazaki W, Kurihara H, Tanaka H, et al. Modification of mineralocorticoid receptor function by Racl GTPase: implication in proteinuric kidney disease. Nat Med (2008) 14:1370-6. doi:10.1038/ nm. 1879

184. Schaldecker T, Kim S, Tarabanis C, Tian D, Hakroush S, Castonguay P, et al. Inhibition of the TRPC5 ion channel protects the kidney filter. J Clin Invest (2013) 123:5298-309. doi:10.1172/JCI71165

185. Blattner SM, Hodgin JB, Nishio M, Wylie SA, Saha J, Soofi AA, et al. Divergent functions of the Rho GTPases Racl and Cdc42 in podocyte injury. Kidney Int (2013) 84:920-30. doi:10.1038/ki.2013.175

186. Huber TB, Hartleben B, Winkelmann K, Schneider L, Becker JU, Leitges $\mathrm{M}$, et al. Loss of podocyte aPKClambda/iota causes polarity defects and nephrotic syndrome. J Am Soc Nephrol (2009) 20:798-806. doi:10.1681/ASN. 2008080871

187. Satoh D, Hirose T, Harita Y, Daimon C, Harada T, Kurihara H, et al. aPKClambda maintains the integrity of the glomerular slit diaphragm through trafficking of nephrin to the cell surface. J Biochem (2014) 156(2):115-28. doi:10.1093/jb/mvu022

188. Soda K, Balkin DM, Ferguson SM, Paradise S, Milosevic I, Giovedi S, et al. Role of dynamin, synaptojanin, and endophilin in podocyte foot processes. J Clin Invest (2012) 122:4401-11. doi:10.1172/JCI65289

189. Arif E, Wagner MC, Johnstone DB, Wong HN, George B, Pruthi PA, et al. Motor protein Myolc is a podocyte protein that facilitates the transport of slit diaphragm protein Neph1 to the podocyte membrane. Mol Cell Biol (2011) 31:2134-50. doi:10.1128/MCB.05051-11

190. Krendel M, Osterweil EK, Mooseker MS. Myosin 1E interacts with synaptojanin-1 and dynamin and is involved in endocytosis. FEBS Lett (2007) 581:644-50. doi:10.1016/j.febslet.2007.01.021

191. Krendel M, Kim SV, Willinger T, Wang T, Kashgarian M, Flavell RA, et al. Disruption of myosin le promotes podocyte injury. J Am Soc Nephrol (2009) 20:86-94. doi:10.1681/ASN.2007111172

192. Reiser J, Polu KR, Moller CC, Kenlan P, Altintas MM, Wei C, et al. TRPC6 is a glomerular slit diaphragm-associated channel required for normal renal function. Nat Genet (2005) 37:739-44. doi:10.1038/ng1592

193. Winn MP, Conlon PJ, Lynn KL, Farrington MK, Creazzo T, Hawkins AF, et al. A mutation in the TRPC6 cation channel causes familial focal segmental glomerulosclerosis. Science (2005) 308:1801-4. doi:10.1126/science.1106215
194. Conway DE, Breckenridge MT, Hinde E, Gratton E, Chen CS, Schwartz MA. Fluid shear stress on endothelial cells modulates mechanical tension across VE-cadherin and PECAM-1. Curr Biol (2013) 23:1024-30. doi:10.1016/j.cub. 2013.04.049

195. Mathieson PW. The podocyte as a target for therapies - new and old. Nat Rev Nephrol (2012) 8:52-6. doi:10.1038/nrneph.2011.171

196. Lin S, Li D, Jia J, Zheng Z, Jia Z, Shang W. Spironolactone ameliorates podocytic adhesive capacity via restoring integrin alpha 3 expression in streptozotocininduced diabetic rats. J Renin Angiotensin Aldosterone Syst (2010) 11:149-57. doi:10.1177/1470320310369603

197. Xing CY, Saleem MA, Coward RJ, Ni L, Witherden IR, Mathieson PW. Direct effects of dexamethasone on human podocytes. Kidney Int (2006) 70:1038-45. doi:10.1038/sj.ki.5001655

198. Yu CC, Fornoni A, Weins A, Hakroush S, Maiguel D, Sageshima J, et al. Abatacept in B7-1-positive proteinuric kidney disease. N Engl J Med (2013) 369:2416-23. doi:10.1056/NEJMoa1304572

199. Goodman SL, Picard M. Integrins as therapeutic targets. Trends Pharmacol Sci (2012) 33:405-12. doi:10.1016/j.tips.2012.04.002

200. Lin X, Suh JH, Go G, Miner JH. Feasibility of repairing glomerular basement membrane defects in Alport syndrome. J Am Soc Nephrol (2014) 25:687-92. doi:10.1681/ASN.2013070798

201. Liu XL, Done SC, Yan K, Kilpelainen P, Pikkarainen T, Tryggvason K. Defective trafficking of nephrin missense mutants rescued by a chemical chaperone. JAm Soc Nephrol (2004) 15:1731-8. doi:10.1097/01.ASN.0000129826.28932.FD

202. Arif E, Rathore YS, Kumari B, Ashish F, Wong HN, Holzman LB, et al. Slit diaphragm protein Neph1 and its signaling: a novel therapeutic target for protection of podocytes against glomerular injury. J Biol Chem (2014) 289:9502-18. doi:10.1074/jbc.M113.505743

Conflict of Interest Statement: The authors declare that the research was conducted in the absence of any commercial or financial relationships that could be construed as a potential conflict of interest.

Received: 15 July 2014; accepted: 21 September 2014; published online: 14 October 2014.

Citation: Lennon R, Randles MJ and Humphries MJ (2014) The importance of podocyte adhesion for a healthy glomerulus. Front. Endocrinol. 5:160. doi: $10.3389 /$ fendo.2014.00160

This article was submitted to Diabetes, a section of the journal Frontiers in Endocrinology.

Copyright $\odot 2014$ Lennon, Randles and Humphries. This is an open-access article distributed under the terms of the Creative Commons Attribution License (CC BY). The use, distribution or reproduction in other forums is permitted, provided the original author(s) or licensor are credited and that the original publication in this journal is cited, in accordance with accepted academic practice. No use, distribution or reproduction is permitted which does not comply with these terms. 